University of Nebraska - Lincoln

DigitalCommons@University of Nebraska - Lincoln

Biological Systems Engineering: Papers and

Publications

Biological Systems Engineering

2006

\title{
Land Application of Manure for Beneficial Reuse
}

L. M. Risse

University of Georgia, mrisse@uga.edu

M. L. Cabrera

University of Georgia

A. J. Franzluebbers

USDA-ARS Watkinsville, Georgia, alan.franzluebbers@ars.usda.gov

J. W. Gaskin

University of Georgia, jgaskin@uga.edu

John E. Gilley

University of Nebraska-Lincoln, john.gilley@ars.usda.gov

See next page for additional authors

Follow this and additional works at: https://digitalcommons.unl.edu/biosysengfacpub

Part of the Biological Engineering Commons

Risse, L. M.; Cabrera, M. L.; Franzluebbers, A. J.; Gaskin, J. W.; Gilley, John E.; Killorn, R.; Radcliffe, D. E.;

Tollner, W. E.; and Zhang, H., "Land Application of Manure for Beneficial Reuse" (2006). Biological Systems Engineering: Papers and Publications. 65.

https://digitalcommons.unl.edu/biosysengfacpub/65

This Article is brought to you for free and open access by the Biological Systems Engineering at DigitalCommons@University of Nebraska - Lincoln. It has been accepted for inclusion in Biological Systems Engineering: Papers and Publications by an authorized administrator of DigitalCommons@University of Nebraska Lincoln. 


\section{Authors}

L. M. Risse, M. L. Cabrera, A. J. Franzluebbers, J. W. Gaskin, John E. Gilley, R. Killorn, D. E. Radcliffe, W. E. Tollner, and $\mathrm{H}$. Zhang 


\title{
LAND APPLiCATION OF MANURE FOR BENEFICIAL REUSE
}

\author{
L. M. Risse ${ }^{1}$, M. L. Cabrera ${ }^{1}$, A. J. Franzluebbers ${ }^{2}$, J. W. Gaskin ${ }^{1}$, \\ J. E. Gilley ${ }^{3}$, R. Killorn ${ }^{4}$, D. E. Radcliffe ${ }^{1}$, W. E. Tollner ${ }^{1}$, H. Zhang ${ }^{5}$
}

\begin{abstract}
SUMMARY
The concentration of animal production systems has increased efficiency and improved overall economic return for animal producers. This concentration, along with the advent of commercial fertilizers, has led to a change in the way animal producers view manure. Manure, once valued as a resource by farmers, is now treated as a waste. Air and water quality concerns that arise primarily from the under-utilization or inefficient use of manure contribute to these changing views. However, when properly used, manure is a resource and should be regulated as such. In the United States, the USDA/EPA Unified National Strategy for Animal Feeding Operations outlines how animal feeding operations should be regulated and acknowledges that land application at proper agronomic rates is the preferred use for manures. However, many limitations such as water quality concerns, uncertainty in manure nutrient availability, high transportation costs, and odor concerns cause some to question land application. This paper documents the benefits of land application of manure, discusses limitations that hinder greater manure utilization, and outlines research and extension needs for improving manure utilization.
\end{abstract}

\section{INTRODUCTION}

Manure is an excellent source of major plant nutrients such as nitrogen, phosphorus, and potassium, as well as the secondary nutrients that plants require. Plant nutrients in commercial fertilizers are mostly water soluble and readily available for plant uptake, while the nutrients in manure are less available. This complicates the determination of application rates but the slower release contributes to improved plant utilization and decreased nutrient losses to surface and ground water. Many studies have demonstrated that crop yields on land application areas are equivalent or superior to those attainable with inorganic fertilizers. Crop quality has also been improved by manure additions. These improved responses are usually attributed to manure-supplied nutrients or improved soil conditions not provided by inorganic fertilizer. Manure, especially poultry litter, can also neutralize soil acidity and raise soil $\mathrm{pH}$. This liming effect can further increase the value of manure.

Research has shown manure application can have a significant impact on the chemical, physical and biological properties of the soil. Most of these effects are due to an increase in soil organic matter resulting from manure application. The ability of manure to promote formation of water-stable aggregates in the soil has a profound effect on soil structure and physical characteristics. Waterstable aggregates increase infiltration, porosity, and water holding capacity and decrease soil compaction and erosion. Through improvement in soil physical properties, manure application also reduces the energy required for tillage and the impedance to seedling emergence and root penetration. Soil organic matter is known to affect a number of soil chemical properties such as the cation exchange capacity and the soil buffering capacity that enable manure treated soils to retain nutrients and other chemicals for longer periods of time. Soil organic matter is known to affect activity, degradation, and persistence of pesticides, and several studies have shown reduced pesticide losses from manure treated fields.

\footnotetext{
${ }^{1}$ L. M. Risse, M. L. Cabrera, J.W. Gaskin, D. E. Radcliffe, and W.E. Tollner, University of Georgia

2 A. J. Franzluebbers, USDA-ARS Watkinsville, Georgia

3 J.E. Gilley, USDA-ARS, Lincoln, Nebraska

${ }^{4}$ R. Killorn, Iowa State University

${ }^{5}$ H. Zhang, Oklahoma State University
} 
The land application of manure can affect soil erosion and surface water runoff. Several laboratory and rainfall simulator studies on manure-amended soils indicate runoff and erosion rates are influenced by manure characteristics, loading rates, incorporation and the time between application and the first rainfall. The broad range of research objectives, underlying assumptions, manure types, and environmental conditions create differing results. Field plots established to collect runoff from natural precipitation events consistently indicate that manure can substantially reduce both runoff and soil erosion when solid manures are land applied. Results using lagoon effluent or slurries are less conclusive. Nevertheless, this is a substantial benefit that should be considered when determining the water quality impacts of land application.

Land application of animal manures can help mitigate potentially negative consequences of rising atmospheric $\mathrm{CO}_{2}$ on the global climate by contributing to greater sequestration of carbon in soil. In general, soil organic carbon sequestration on an area basis appears to be greater with an increased rate of manure application. Climate appears to affect potential retention of applied carbon in soil with warmer regions tending to have lower carbon retention rates from manure $(7 \pm 5 \%)$ than temperate or frigid regions $(23 \pm 15 \%)$. Methane is also a significant contributor to global warming and animal agriculture is a significant contributor of methane emissions globally. Land application of manure can significantly decrease the net quantity of methane emitted to the atmosphere compared with stockpiling or long-term lagoon storage of manure.

The benefits of utilizing manure through land application are apparent. However, there are several impediments that discourage greater use of manure nutrients in cropping systems. These include potential water quality problems associated with runoff, uncertainty associated with the nutrient availability, high transportation and handling costs that discourage transport and greater utilization, and public perception or odor issues.

Potential pollutants of concern in livestock wastes are organic materials, nutrients, and pathogenic microorganisms. Surface water is primarily affected through soluble contaminants in runoff or insoluble pollutants carried on soil particles during soil erosion events. Groundwater can be contaminated with excessive pollutants from percolation, seepage, and direct infiltration. Nutrients are the most common pollutant associated with animal waste. Several studies have documented that watersheds with predominantly animal agriculture tend to have higher nutrient levels in their drainage systems. Over-application of manure to crops or grasses can result in leaching of nitrate to ground water or high levels of $\mathrm{N}$ in surface waters resulting in eutrophication and low dissolved oxygen levels. Research has shown that the concentration of $\mathrm{P}$ in runoff increases as the $\mathrm{P}$ concentration in the topsoil increases. Manure presents a special problem because the N-to-P ratio in manures is lower than that needed by crops. As a result of the low N-to-P ratio in manure, excess $\mathrm{P}$ builds up to environmentally harmful levels in fields that receive repeated applications. Compared to $\mathrm{N}$ and $\mathrm{P}$, much less research has been done on bacteria and other pathogens in manures and their impact on water quality.

The primary way to reduce the risks associated with land application of manure involves addressing the application rate, timing, and location. These issues are commonly addressed through nutrient management planning. The USDA/EPA Unified National Strategy for Animal Feeding Operations establishes a national performance expectation that all AFOs should develop and implement technically sound, economically feasible Comprehensive Nutrient Management Plans (CNMPs). Traditionally, nutrient management has involved optimizing the economic return from nutrients used for crop production. Today, the agronomic and economic requirements of nutrient management remain central, but the process is being expanded to include the potential environmental impacts of nutrients on the entire farm operation. This increases both the cost and complexity of these plans, yet few studies have documented the effectiveness of nutrient management plans and some studies suggest it is difficult for farmers to reduce environmental impacts even with welldeveloped plans. Often nutrient management plans do result in benefits for farmers and society, especially as an educational process, however, implementation has not been as great as desired.

Even under ideal conditions, there is still a significant risk of losses to the environment. Agricultural systems leak and elimination of non-point source impacts is practically impossible. Therefore, secondary treatment or preventative systems should also be incorporated into the design of all land application systems regardless of the choice of nutrient source. There are a number of best management practices (BMPs) that can be adopted to reduce the water quality impact of land-applied 
manure. The method and timing of manure application can be adjusted to reduce the amounts of constituents transported in runoff. Practices that limit soil erosion or runoff will positively impact surface water quality, while practices that reduce leaching should help prevent groundwater contamination. Conservation tillage, contouring and strip cropping, terraces, and vegetated waterways have all been used effectively to minimize runoff. Narrow grass hedges have also been employed to reduce runoff, control erosion, decrease nutrient transport, and provide wildlife habitat. Secondary treatment systems such as vegetative buffer zones, grass filter strips, riparian zones, and/or other vegetative filters can prevent nutrient and pathogen movement to surface waters. Containment systems like ponds and diversions may also be used. Ultimately, the goal of these systems should not be treatment, but should be a secondary system that insures that contaminated runoff does not directly enter surface water. The need for these types of systems is highly dependent on the receiving water body as often these secondary systems are not economically justified. Studies addressing the cost-benefit and efficiency of these systems on the farm and comprehensive watershed scale are needed to aid in producer decisions and help with water quality modeling efforts. Educational programs and policies to inform and to encourage adoption of current conservation technologies and BMPs by farmers is also an immediate need.

Farmers often choose to use commercial sources of fertilizers instead of manure because of variability and uncertainty concerning manure nutrient availability. Although estimates of nutritional content can be obtained through published literature, due to the variability in farming practices, animal diets, climate, and waste storage facilities, manure nutrient analysis is usually recommended. Currently, most farmers sample their manure regularly but wait extended periods for test results. The development of inexpensive, on-farm nutrient tests would allow for testing at the time of application and more frequent and dependable test results. Obtaining representative manure samples presents unique challenges depending on the physical nature of the manure involved. In the case of wet manure, one of the main sampling challenges is to obtain a representative sample from manure slurry that has different liquid and solid phases.

Where animal production is concentrated, the land base available for manure application is usually limited. This limitation arises from restrictions imposed by the economics of manure transportation. The transport, collection, intermediate storage and general handling of manure to and from the point of processing or use is and will continue to be a problem. Little research emphasis is being placed on the concepts of materials handling and metering for animal manure, yet the economics of transporting the material to the point of use is often the greatest concern limiting the livestock producers from maximizing the use of this biomass resource. The export of manure from surplus to deficit areas for use as a fertilizer is often economically viable at larger scales. However, large scale transfers of manure are not occurring, suggesting a need for increases in the incentives given to commercial firms to provide manure brokering. Better integration of farms that produce crops and livestock and educational programs aimed at showing farmers the economic value of manure as a fertilizer are other methods of reducing the transport costs. Separation, screening, condensing, and dewatering technologies could also be used to produce more transportable products; however, little research is being conducted in these areas.

Public perception of agriculture in general and land application in particular is critical to continued acceptance of manure application as the primary utilization strategy. Public concerns with animal manures can be broken into three major categories; water quality, air quality, and food quality. Land application of manures has the potential to negatively impact all three. Improved technical information should to be communicated to the general public about environmental, social and political concerns and potential solutions.

\section{HISTORICAL PERSPECTIVES}

Traditional American agriculture often includes a vision of a farm with a diversity of animals and a flock of chickens being raised in addition to other labor demands of the crop production enterprise. It was routine for the farm wife to be responsible for the management of the chicken flock, and to market eggs and fryers as an ongoing source of cash (Miner et al., 2000). Dairy herd size was frequently less than 20 cows. Poultry flocks ran on grounds near the farmhouse. Draft animals placed demands on the resources of the farm for feed production. Agricultural waste was not a seri- 
ous problem because of the extensive nature of the operations. Manure was viewed as an agricultural resource during the formative years of agriculture in the $17^{\text {th }}$ through the $19^{\text {th }}$ centuries (Burn, 1889; Murray, 1910). Manure provided nutrients in slow release form (Buckman and Brady, 1969). Manure application helped maintain soil organic matter (SOM), which in turn resulted in increased water infiltration and reduced soil erosion. This helped the farmer grow feed as well as other crops for export off the farm.

World War II brought about profound changes in American life and agriculture. The farm labor supply was short during the war. The end of the war resulted in an excess capacity for fuel and nitrogen-based munitions that could be converted into inorganic fertilizer production capacity. Urban populations, with their promise of regular hours and better pay, grew at unprecedented rates in the middle of the last century. Urban population growth, farm labor shortages, the ingenuity of the American farmer with the support of Land Grant Agricultural Experiment Stations, abundant energy and nutrients, excellent soils and favorable climate provided the foundation for the ability to produce feed, food and fiber with incredible efficiency. The American farmer and consumer now have a consistent and high quality supply of meat, dairy and poultry products, largely due to efficient production methods.

Increases in production efficiency resulted in dense concentrations of beef, dairy, swine, and poultry animals. The resulting concentration of manure has created potential environmental problems. These problems contributed in part to the passage of the Clean Water Act in 1972. Because of the significant imbalance in manure nitrogen compared to available nearby cropland at many production centers, manure is now often viewed as a disposal problem. Urban encroachment into historic animal production regions sometimes results in conflicts over water and air quality issues and odors. These problems caused some to question the appropriateness of land application as a sound manure utilization strategy.

Animal manure is by far the largest byproduct resulting from animal production. The total quantity of collectable manure produced in the United States is estimated to be over 61 million tons per year on a dry weight basis including approximately 1.12 million $\mathrm{Mg}$ of nitrogen $(\mathrm{N})$ and 0.60 million Mg of phosphorus (P) (CAST, 1996; Gollehon et al., 2001). In the United States, the Department of Agriculture and the Environmental Protection Agency have determined that land application of manure at proper agronomic rates is the most desirable method for utilizing manure resources (USDA-EPA, 1999). While the utilization of manure offers benefits such as increases in soil fertility and quality, reductions in runoff and soil erosion, and opportunities for carbon (C) sequestration, improper use can impair water quality and produce odor and air quality concerns. Based on an analysis of manure's potential fertilizer value, recoverable $\mathrm{N}$ in manure represents about $15 \%$ of the $\mathrm{N}$ and $42 \%$ of the P purchased in the United States as crop fertilizers (CAST, 1996). If properly distributed and utilized on productive cropland, manure could substantially reduce commercial fertilizer purchases. However, when applied at excessive rates, manure can cause water quality impairments.

This paper provides a summary of the benefits derived from the land application of manure. It then discusses limitations and concerns involved in manure application, and concludes with a review of research and extension needs to validate continued land application of manure.

\section{BENEFITS OF MANURE APPLICATION}

Land application of manure provides many benefits to farmers and society. Manure serves as an excellent source of both primary and secondary nutrients required for crop growth. In addition, land application improves overall soil quality that supplies indirect benefits to the farmer through improved crop response, reductions in inorganic inputs of fertilizers, liming materials, and pesticides, and reduced soil and water losses. Society can obtain other benefits such as improved water quality and carbon sequestration through proper agronomic use of manure. This section provides the scientific documentation for these benefits.

\section{Manure Serves as a Fertilizer}

Manure is an excellent source of major plant nutrients such as N, P, and potassium (K) and also provides many of the secondary nutrients that plants require. The actual nutrient value of manure 
Table 1. Nutrient analysis of manure for various handling systems (Bates and Gagon, 1981).

\begin{tabular}{|ccccccc|}
\hline & \multicolumn{3}{c}{ Nonliquid Systems $(\mathbf{k g} / \mathbf{M g})$} & \multicolumn{3}{c|}{ Liquid Systems $(\mathbf{K g} / \mathbf{1 , 0 0 0} \mathbf{L})$} \\
\cline { 2 - 7 } Animal Species & $\mathbf{N}$ & $\mathbf{P}_{\mathbf{2}} \mathbf{O}_{\mathbf{5}}$ & $\mathbf{K}_{\mathbf{2}} \mathbf{0}$ & $\mathbf{N}$ & $\mathbf{P}_{\mathbf{2}} \mathbf{O}_{\mathbf{5}}$ & $\mathbf{K}_{\mathbf{2}} \mathbf{0}$ \\
\hline Dairy & $3-8$ & $1-8$ & $1-16$ & $0.4-6.1$ & $0.2-2.5$ & $0.2-6.9$ \\
Beef & $2-10$ & $1-7$ & $2-15$ & $0.7-4.4$ & $0.1-3.5$ & $0.6-3.6$ \\
Swine & $2-14$ & $1-31$ & $1-9$ & $0.1-7.3$ & $0.1-7.5$ & $0.1-5.9$ \\
Poultry & $2-66$ & $1-48$ & $1-28$ & $4.2-9.0$ & $1.6-10.9$ & $1.6-4.7$ \\
\hline
\end{tabular}

from a particular operation will differ considerably due to the type of animal, its food ration, method of collection and storage, method of application and climate. Estimated fertilizer nutrient contents for various manures are shown in Table 1. Nutrients in manure may be lost or transformed during treatment, storage and handling affecting their availability for use by growing plants.

Animal manures are important sources of both micro and macronutrients for plants, but their application rates are usually determined based on the content of macronutrients such as $\mathrm{N}, \mathrm{P}$, and $\mathrm{K}$. Plants can only use nutrients that are in an inorganic form. Manure $\mathrm{N}$ and $\mathrm{P}$ are present in organic and inorganic forms, and are not considered $100 \%$ available to plants. The organic forms must be mineralized or converted into inorganic forms over time before plants can use them. The availability of $\mathrm{K}$ in manure is considered similar to that in commercial fertilizer since the majority of $\mathrm{K}$ in manure is in the inorganic form (Motavalli et al., 1989). In general, 90 to $100 \%$ of $\mathrm{K}$ in the manure is considered available during the first year of application.

Available Nitrogen

When using manure as a fertilizer, knowledge of the $\mathrm{N}$ that is available to the plant is critical to insuring that plant nutrient needs are met. The following model has been proposed for estimating available N in animal manures (Beauchamp, 1983; Sims, 1986):

$$
\text { Available } \mathrm{N}=\mathrm{F}_{\mathrm{i}} \mathrm{N}_{\mathrm{i}}+\mathrm{F}_{\mathrm{m}} \mathrm{N}_{\mathrm{o}}
$$

where:

$\mathrm{N}_{\mathrm{i}}$ and $\mathrm{N}_{\mathrm{o}}$ = inorganic and organic $\mathrm{N}$, respectively

$\mathrm{F}_{\mathrm{i}}=$ the fraction ( 0 to 1$)$ of inorganic $\mathrm{N}$ that is available

$\mathrm{F}_{\mathrm{m}}=$ the fraction ( 0 to 1$)$ of organic $\mathrm{N}$ that is mineralizable or decomposable to inorganic $\mathrm{N}$

Inorganic $\mathrm{N}$ in the above equation is multiplied by an availability factor because $\mathrm{N}$ losses (through nitrate leaching, ammonia volatilization, and denitrification) and microbial immobilization can reduce the amount of inorganic $\mathrm{N}$ available for plant uptake. Similarly, organic $\mathrm{N}$ is multiplied by a mineralizable fraction $\left(\mathrm{F}_{\mathrm{m}}\right)$ because not all of the organic $\mathrm{N}$ in animal manure can be converted to inorganic $\mathrm{N}$ and become available to plants. The importance of each of the terms in the model depends on the relative proportion of organic and inorganic $\mathrm{N}$ in the manure under consideration. In general, dry and composted manure contains less inorganic than organic N. Expressed as a percentage of total $\mathrm{N}$, inorganic $\mathrm{N}$ has been found to make up 1 to $11 \%$ in cattle manure, 4 to $15 \%$ in swine manure, 3 to $50 \%$ in poultry manure, and 1 to $13 \%$ in composted manure (Cabrera and Gordillo, 1995). On the other hand, slurries commonly contain more inorganic than organic N. Expressed as a percentage of total $\mathrm{N}$, inorganic $\mathrm{N}$ has been found to range from 60 to $79 \%$ in cattle slurry (Sommer et al., 1992), from 68 to $89 \%$ in swine slurry (Sommer et al., 1992), and from 84 to 95\% in poultry slurry (Beauchamp, 1986). Consequently, the most important component of plant available $\mathrm{N}$ is usually inorganic $\mathrm{N}$ in slurries and mineralizable $\mathrm{N}$ in dry and composted manure.

\section{Available Inorganic Nitrogen}

Inorganic $\mathrm{N}$ in manure is relatively easy to measure by routine analytical laboratories. Furthermore, there are rapid on-farm methods that can provide fairly accurate estimates of the concentration of ammonium in manure slurries (Van Kessel et al., 2000). Because most of the N in slurries is present as ammonium (Sommer et al., 1992), these rapid methods are useful for predicting plant available $\mathrm{N}$ in conjunction with estimates of the availability of the ammonium $\mathrm{N}$ which is present. The availability of inorganic $\mathrm{N}\left(\mathrm{F}_{\mathrm{i}}\right)$ in slurries can vary with the method of slurry application because the main mechanism of $\mathrm{N}$ loss can change with method of application. In general, the main 
mechanism of $\mathrm{N}$ loss is ammonia volatilization for surface applications and denitrification for injected or incorporated applications.

Surface application of manure slurries has resulted in ammonia losses ranging from 33 to $89 \%$ of the applied ammonium (Sommer et al., 1991; Sharpe and Harper, 1997). These losses would correspond to availability factors ranging from 0.11 to 0.67 . Injection of slurries has caused denitrification losses ranging from 7 to $21 \%$ of the applied $\mathrm{N}$ (Thompson et al., 1987), which would correspond to a range of 0.79 to 0.93 in the availability factor. Thus, the availability of inorganic $\mathrm{N}$ in slurries may be larger when injected than when surface-applied.

Data on the availability of inorganic $\mathrm{N}$ in fresh manure are scarce, but in a study with surfaceapplied poultry litter, Marshall et al. (1998) measured ammonia losses that ranged from 28 to $46 \%$ of the ammonium applied. Considering that ammonium in the poultry litter used made up 65 to $85 \%$ of the inorganic $\mathrm{N}$, the corresponding availability factor for inorganic $\mathrm{N}$ ranged from 0.60 to 0.82. In a laboratory study with poultry litter incorporated into soil, Cabrera et al. (1994) found denitrification losses that corresponded to $33 \%$ of the inorganic $\mathrm{N}$ initially present in the litter. This would correspond to an availability factor of 0.67 . Although limited in scope, these results suggest that the availability of inorganic $\mathrm{N}$ in poultry litter may be similar in surface-applied and incorporated applications. Additional research is needed to develop availability factors for inorganic $\mathrm{N}$ in slurries and fresh manure applied using varying methods and under different environmental conditions.

\section{Available Organic Nitrogen}

Mineralizable $\mathrm{N}$ has been traditionally estimated with biological and chemical methods because it is more difficult to measure than inorganic N. Biological methods predict mineralizable $\mathrm{N}$ by incubating a manure-soil mixture during an extended period of time and determining the inorganic $\mathrm{N}$ released during the incubation (Qafoku et al., 2001). In contrast, chemical methods estimate mineralizable $\mathrm{N}$ by extracting or measuring a chemical fraction that is related to mineralizable $\mathrm{N}$ (Serna and Pomares, 1991). Although biological methods are more accurate than chemical methods, they are not practical for routine laboratory analysis because they are laborious and time consuming. Chemical methods are faster and thus more desirable for routine analysis. Work with biological methods has generated estimates of the fraction of organic $N$ that is mineralizable $\left(F_{m}\right)$ in some manure. Values have ranged from 0.08 to 0.52 for swine manure, from 0 to 0.51 for cattle manure, and from 0.17 to 0.73 for poultry litter (Cabrera and Gordillo, 1995).

A chemical method applicable to all manure has not yet been developed, but work with specific manure types has shown promising results. For example, mineralizable $\mathrm{N}$ in poultry litter has been found to be strongly related to total $\mathrm{N}$ and uric acid concentrations $\left(\mathrm{r}^{2}=0.91\right.$; Gordillo and Cabrera, 1997), and to water-soluble organic $\mathrm{N}\left(\mathrm{r}^{2}=0.87\right.$; Qafoku et al., 2001). In addition, recent work has shown the feasibility of using near infrared reflectance spectroscopy to estimate mineralizable $\mathrm{N}$ in dairy manure (Reeves and Van Kessel, 1999) and poultry litter (Qafoku et al., 2001).

\section{Available Phosphorus}

Available $\mathrm{P}$ in manure is made up of inorganic $\mathrm{P}$ and mineralizable P. Some researchers have reported that the availability of $\mathrm{P}$ in manure is equal to or superior to that of inorganic fertilizers (During and Weeda, 1973; May and Martin, 1966); others have shown lower responses from manure than fertilizer P (Goss and Stewart, 1979; Motavalli et al., 1989). Although data on manure P availability are limited, it is currently assumed that 80 to $90 \%$ of manure $\mathrm{P}$ is plant available because inorganic P commonly makes up 60 to $90 \%$ of total P (Gerritse and Vriesema, 1984; Barnett, 1994b; Sharpley and Moyer, 2000). The extent of research on manure P availability has been limited because manure has been typically applied based on the $\mathrm{N}$ requirements of plants, which leads to an over-application of $\mathrm{P}$ and eliminates the need to accurately estimate plant available P. More accurate estimates of plant available $\mathrm{P}$ in animal manure will be needed as current concerns with $\mathrm{P}$ contamination of surface waters lead to manure applications based on P requirements.

\section{Crops Respond to Manure}

Animal manure is an excellent nutrient source because it contains most of the plant essential elements (Follett et al., 1992; Jokela, 1992; Sawyer et al., 1992; Xie and MacKenzie, 1986). The potential value of manure as a source of plant nutrients for crop production is great although the concentrations of nutrients in the manure tend to be low. Over the last decade, great numbers of 
confined animal feeding operations have resulted in an increase in the amount of manure available. Many studies have demonstrated that land application of manure will produce crop yields equivalent or superior to those obtained with chemical fertilizers (Motavalli et al., 1989; Xie and MacKenzie, 1986). Crop quality has also been improved by manure application (Eck et al., 1990; Pimpini et al., 1992). When crop improvements with manure were greater than those attained with commercial fertilizer, response was usually attributed to manure supplied nutrients or to improved soil conditions not provided by commercial fertilizer (CAST, 1996). Zhang et al. (1998) found that $2 \mathrm{~kg}$ of manure- $\mathrm{N}$ were equivalent to $1 \mathrm{~kg}$ of urea-N in terms of plant uptake and yield response in the first year of cattle feedlot manure application.

Manure improves the physical condition of the soil and increases $\mathrm{P}$ and biological activity (CAST, 1996; Sommerfeldt and Chang, 1985; Chang et al., 1990). The organic matter, total N content, and the micronutrient content of the surface soil are increased as a result of manure application. More studies are needed to quantify the benefits of manure nutrients other than $\mathrm{N}$ and the economic advantage associated with these improvements.

\section{Manure Maintains Soil pH}

Most people recognize the value of manure as a plant nutrient source or soil amendment, but the potential of manure, especially poultry litter, to neutralize soil acidity and raise soil $\mathrm{pH}$ is less known. Long-term field and greenhouse studies have demonstrated the liming effect of animal manure in acid and neutral soils. The Magruder Plots at Oklahoma State University Agronomy Research Farm in Stillwater are the oldest continuous soil fertility wheat research plots in the Great Plains region (Boman et al., 1996). Animal manure has been applied on some of these plots for many decades. The soil $\mathrm{pH}$ of the top six inches of the manured plots $(\mathrm{pH}$ of 6.32) is greater than those from control plots (5.83), those receiving annual inorganic fertilizer applications $(\mathrm{pH}$ ranges from 5.21 to 5.66), and even those receiving inorganic fertilizer and lime ( $\mathrm{pH}$ of 5.51). Sharpley et al. (1993) conducted a study in Eastern Oklahoma and found the soil $\mathrm{pH}$ of the surface $0.6 \mathrm{~m}$ of soil that received swine and poultry manure for 5 years was significantly higher than the $\mathrm{pH}$ of the soils that received no manure during the same period. Eghball (1999) found beef cattle feedlot manure and compost raised soil $\mathrm{pH}$ while inorganic $\mathrm{N}$ fertilizer application significantly reduced soil $\mathrm{pH}$. Researchers from Alabama studied the impact of long-term (15 years) land application of broiler litter on environmentally related soil properties, and found soil $\mathrm{pH}$ was 0.5 unit higher to a depth of $0.6 \mathrm{~m}$ under littered soils than unlittered counterparts (Kingery, et al., 1994). Another study in Hawaii compared the growth response of a tropical forage legume to lime and organic manure as acid soil amendments in a green house. They found that chicken manure was as effective as lime in raising soil $\mathrm{pH}$ and in reducing aluminum (Al) toxicity (Hue, 1992). This study suggested that tropical forage legumes were able to absorb more $\mathrm{Ca}$ from the manure than from lime.

The main reason manure raises soil $\mathrm{pH}$ is due to materials such as calcium $(\mathrm{Ca})$ and magnesium contained in the manure. For example, poultry litter contains about $50 \mathrm{Kg} \mathrm{Ca}$ per $\mathrm{Mg}$ on a dry weight basis. Therefore, applying manure to acid soils not only supplies much needed nutrients and organic matter for plant growth but also reduces soil acidity, thus improving $\mathrm{P}$ availability and reducing Al toxicity.

\section{Manure Increases Soil Organic Matter}

Research has shown manure application has a significant effect on the chemical, physical and biological properties of the soil (Haynes and Naidu, 1998; Khaleel et al., 1991; Sommerfeldt and Chang, 1985). Most of these effects are due to an increase in soil organic matter (SOM) with manure applications (Haynes and Naidu, 1998). The organic matter deposited enhances soil physical properties such as tilth, structure, water-holding capacity, water infiltration rate, and soil microbial activity (Sweeten and Mathers, 1985). Studies over a wide variety of soil textures, climates and cropping systems report increases in SOM with manure addition (Aoyama et al., 1999; Brown et al., 2000; Fraser et al., 1988; Haynes and Naidu, 1998; Kandeler et al., 1999; Kingery et al., 1993; Kubat et al., 1999; Nyakatawa et al., 2001; Porter et al., 1999; Stewart, 1991; Vitosh et al., 1973; Tiarks et al., 1974). The SOM increase is due to both the organic matter input from the manure and to greater plant growth in response to nutrients, which increases root biomass and residues for incorporation into SOM. 
The rate of increase in SOM depends on temperature, moisture and tillage conditions, as well as the amount of manure added. Nyakatawa et al. (2001) reported increases of SOM of 55 to $80 \%$ in the silt loam soils of northern Alabama after three years of poultry litter additions. Most studies indicate at least two years of manure additions are necessary to see increases in SOM (Stewart, 1991). Manure application can also reduce SOM losses in production systems under tillage (Aoyama et al., 1999; Kapkiyai et al., 1999). Manure application increases the protected pools of C in small macroaggregates (Aoyama et al., 1999) and microaggregates (Kapkiyai et al., 1999). Manure is also more effective than plant residues in replenishing particulate SOM (Kapkiyai et al., 1999) that is associated with stabilized organic matter in many agricultural systems.

Organic matter is known to influence a number of chemical properties of the soil. One well known effect is a $\mathrm{pH}$ dependent change in cation exchange capacity (CEC) through the dissociation of carboxyl, phenolic, and hydroxyl groups on the organic molecules that compose SOM (Tisdale et al., 1993). The form and size-fraction of SOM affects its contribution to CEC. Recent research from sandy sub-Saharan soils indicates an increase in CEC due to manure application only when claysized particulate organic matter is present (Guibert et al., 1999). Due to the buffering capacity of organic matter, in acidic soils, manure tends to increase soil pH (Brown et al., 2000; Kingery et al., 1993; Wong et al., 1998), and decrease $\mathrm{pH}$ in alkaline soils (Wahid et al., 1998). In regions where $\mathrm{P}$ is deficient, manure supplies $\mathrm{P}$ and also makes $\mathrm{P}$ more available by complexing Al. The organic complexing of Al also reduces Al toxicity (Haynes and Mokolobate, 2001). Manure can also be used to improve crop production in saline and sodic soils under certain conditions (Dubrey and Mondal, 1994; Wahid et al., 1998).

\section{Manure Improves Physical Soil Properties}

The ability of manure to promote the formation of water-stable aggregates (WSA) has a profound effect on soil structure and thus on soil physical characteristics (Haynes and Naidu, 1998). Numerous studies have shown increases in WSA with manure application (Albiach et al., 2001; Angers, 1998; Barthes et al., 1999; Brown et al., 2000; Estevez et al., 1996; Porter et al., 1999). However, high rates of manure application can disperse soil structure by creating high concentrations of monovalent cations and hydrophobic compounds (Haynes and Naidu, 1998; Paré et al. 1999). A high percentage of WSA increases infiltration (Roberts, 2000), porosity (Kirchmann and Gerzabek, 1999), and water-holding capacity (Mosaddeghi et al., 2000). WSA are also associated with decreased compaction (Mosaddeghi et al., 2000) and erosion (Barthes et al., 1999). Angers (1998) reported that even in silty clay soils with high organic matter contents, the addition of manure increases macro-aggregation, which helps prevent structural degradation. Other research has shown that manure application to fine textured soils (silty clay loams) reduced compaction and increased trafficability (Mosaddeghi et al., 2000). Schjonning et al. (1994) in a study of sandy loam soils in a 90 -year fertilization experiment in Denmark, showed that manured soils had less compaction under large stresses compared to inorganic fertilized or unfertilized soil at comparable water contents and bulk densities. This study indicated that the greater SOM in manured soils increased soil friability. These changes in soil physical properties allow the soil to be worked under wetter conditions. Through improvement in soil physical properties, manure application also reduces the energy required for tillage and the impedance to seedling emergence and root penetration (Eghball and Power, 1994).

\section{Manure Reduces Pesticide Dependence}

The presence and forms of organic $\mathrm{C}$ in the soil affects the structure and complexity of the soil food web, which in turn, affects nutrient cycling and both plant diseases and parasites. Most research indicates that microbial biomass and activity increases with manure additions (Estevez et al., 1996; Haynes and Naidu, 1998; Kandeler et al., 1999; Lalande et al., 2000; Lazarovits, 2001). With increases in microbial populations, shifts in nutrient cycling occur. Several studies indicate manure additions increase bacteria involved in the nitrogen cycle. Lalande et al. (2000) reported an increase in the nitrogen mineralizer population after application of liquid swine manure. Kubat et al. (1999b) showed an increase in nitrification with manure addition compared to mineral fertilizers on a fallow field. These increases can be beneficial in terms of supplying crop nutrients, but can contribute to nitrate leaching if manure is applied at high rates. 
Plant diseases can decrease with the increase in microbial biomass and species diversity, because competition between microbial consumers and an increase in predatory species will limit the growth of pathogens. There are two recent studies that report disease suppression with manure by this mechanism. Bullock et al. (1999) found swine manure significantly decreased the occurrence of southern blight (Sclerotium rolfsii) in tomatoes and increased populations of bacteria that are antagonistic to Sclerotia. Aryantha et al. (2000) attributed the suppression of Phytophthora cinnamomi by composted poultry manure to its ability to sustain biological activity of endosporeforming bacteria. This study did not find consistent disease suppression with either fresh or composted cow, sheep or horse manure.

Other work indicates high nitrogen manure, such as that from poultry and swine, can suppress diseases by generating high ammonia and/or nitrous acid concentrations in the soil (Lazarovits, 2001). Preliminary testing of additions of anhydrous ammonia and synthetic nitrite additions indicated these do not provide the same disease control. Volatile fatty acids and acetic acid in swine manure were also shown to be effective reducing verticillium wilt and potato scab (Lazarovits, 2001). The ability of manure to generate a sufficient concentration of these compounds to suppress disease depended on $\mathrm{pH}$, organic matter content, buffering capacity and nitrification rate of the soil.

Reported manure effects on plant-parasitic nematode populations are variable. Nematodes play an important role in agricultural systems, both as plant parasites and as important contributors to the re-mobilization of nutrients (Coleman et al., 1984). Griffiths et al. (1994) reported decreases in plant parasitic nematodes with poultry manure, but no effects from cattle manure. Neher and Olsen (1999) reported increases in plant-parasitic nematodes in manure-only systems. They indicated the abundance of plant parasitic nematodes were due to a wide variety of factors including quality and quantity of the organic amendment, other soil fertility factors, the use of pesticides, crop rotations and other management factors. Several studies reported increases in bacterivorus nematodes with manure additions (Bohlen and Edwards, 1994; Griffiths et al., 1994; Neher and Olsen, 1999). This may have the effect of increasing availability of nutrients for plant growth (Ingham, 1985).

Organic matter is known to affect activity, degradation, and persistence of pesticides (Benoit et al., 1996; Bollag et al., 1992; Piccolo et al., 1998), and the application rates of some pesticides are based on SOM content. There are several recent laboratory studies reporting manure effects on the leaching and degradation of pesticides. Gan et al. (1998) reported composted manure reduced volatilization of the fungicides methyl bromide and methyl isocyanate. Poultry litter has been shown to double the degradation rate of atrazine (Gupta and Baummer, 1996). This effect may be beneficial in terms of preventing leaching to groundwater and is thought to be due to an increase in microorganism activity. Guo et al. (1991) showed that manure decreased atrazine leaching in coarsetextured soils, though not as effectively as waste activated $\mathrm{C}$ or digested municipal sewage sludge.

Some studies suggest that the agronomic qualities of composted manure are superior to those of raw manure (Rynk, 1994). The stabilized organic matter in high quality composts quickly adds humus to the soil. Land application of composted rather than fresh manure has the potential for reducing weed seed viability and thus reducing herbicides needed (Edwards et al., 1994). Maynard (1994) found that yearly applications of spent mushroom compost and poultry manure compost increased the yields of eight varieties of vegetables when compared to control plots fertilized with equivalent rates of N, P, and K. Part of the advantage that compost offers may lie in the fact that the variety of microbial and biological stimulants in the compost may actually inoculate the soils.

\section{Manure Reduces Runoff and Soil Loss}

As discussed above, soil physical properties such as infiltration, aggregation and bulk density can be improved by manure application (Mielke and Mazurak, 1976; Sommerfeldt and Chang, 1985). The agronomic benefits from the land application of manure can also affect soil erodibility. These changes in soil properties can have a substantial impact on the runoff and soil loss from fields where manure has been land applied.

Several laboratory studies using rainfall simulators have been conducted to measure the effects of manure application on runoff and erosion (Mitchell and Gunther, 1976; Westerman et al., 1983). Runoff and erosion rates were found to be influenced by manure characteristics, loading rates, incorporation and the time between application and the first rainfall. The addition of either swine, cattle or poultry manure in these studies caused a reduction in runoff and soil loss from relatively small laboratory test areas. However, Gilley et al. (1999) found that the long-term application (55 
years) of beef cattle manure at a rate of $27 \mathrm{Mg} / \mathrm{ha}$ to a Tripp sandy loam soil did not significantly influence interrill erosion. Barrington and Madramootoo (1989) investigated seal formation on two soils using a swine manure slurry. They found that manure solids did form seals and the location of these seals was dependent on soil type and the solids content of the slurry. Chandra and De (1983) showed that the effects of manure on soil erosion change with time. In their lab study on several soils in India, soil erosion did not vary on samples where cattle manure was incubated for 15 days while it decreased on samples incubated for 30 days. This may be due to the time required for organic matter in manure to impact soil properties and indicates why longer-term experiments under field conditions may be necessary to determine the impacts of manure on runoff and erosion.

Rainfall simulators have also been used to measure runoff and erosion on field sites where manure has been added. Poultry litter applied to fallow soil was found to cause substantial decreases in runoff and soil loss (Giddens and Barnett, 1980). Reduced soil losses are also reported from the addition of dairy manure to corn plots (Mueller et al., 1984). Bushee et al. (1999) found that runoff from simulated rainfall after swine slurry application was lower, but not significantly different from sites with no manure, and that chemical amendments could alter the amount of runoff produced. Sauer et al. (1999) showed that runoff volumes for treatments with dairy manure or poultry litter were higher or not significantly different under simulated rainfall. However, Gilley and Eghball (1998) found that runoff and erosion immediately following two simulated rainfall events were not significantly influenced by a single application of beef cattle manure or compost under either no-till or tillage conditions. The time period required for beneficial soil properties to develop following manure application is not known. Rainfall simulators have been effectively used to provide valuable data for a given set of experimental conditions. However, repeated rainfall simulation runs would be required to characterize temporal changes in cropping and management factors resulting from land application. Field plots established to collect runoff from natural precipitation events may be better suited for identifying the effects of manure application on annual runoff and soil loss.

When conducting studies of solid manure application and its impact on soil erosion, it is important to distinguish between manure solids loss and soil loss. Westerman et al. (1983) found that solids lost from bare plots treated with poultry litter were between 8 and $92 \%$ greater than solids lost from untreated clay and sandy loam plots. However, Giddens and Barnett (1980) found that solids loss was reduced by as much as $50 \%$ when up to $22.4 \mathrm{Mg}$ /ha of poultry litter was applied to bare plots on a sandy loam soil. Khaleel et al. (1979) developed a soil/manure particle transport model that accounted for different erodibilities of soil and manure particles; however, erodibility values for manure are difficult to determine. Edwards et al. (1994) looked at the relationships between solids yield and the erodibility of poultry litter and litter application rate, rainfall intensity, and interval between litter application and the first rainfall event using simulated rainfall on a fescue pasture. They found the solids yield increased with both litter application rate and rainfall intensity and attributed the increase to the relatively high erodibility of poultry litter particles in comparison to soil. They suggested that water quality models could account for this through an appropriate increase in soil erodibilty (K values) for the first few post-application storms.

Monitoring soil and water losses from natural precipitation events is labor-intensive and expensive. As a result, few studies have recently been initiated in which runoff and soil loss were measured from land application areas. Long et al. (1975) did not report erosion values but did report significantly less runoff over three years from natural runoff plots $(0.04 \mathrm{ha})$ that were treated with 45 $\mathrm{Mg} / \mathrm{ha}$ of dairy manure. Wood et al. (1999) conducted a study on 33 by $33 \mathrm{~m}$ plots planted in corn and rye on a silty clay soil with two rates of broiler litter and a fertilized control. They observed a nonsignificant trend toward reduced runoff on the broiler litter treated plots and significantly lower flow-weighted sediment losses than the fertilizer control in the second year of the study. Vories et al. (1999) found similar results on 0.6 ha cotton fields where treatments that received poultry litter exhibited significantly less total runoff and sediment losses than treatments of commercial fertilizer; however, they noted that sediment concentrations tended to increase on the litter treated plots for events immediately following application. An extensive review of natural runoff plot data was presented by Gilley and Risse (2001). They reviewed more than 70 plot-years worth of data from seven locations under a variety of tillage and cropping conditions. For locations where manure was applied annually, manure treated plots reduced runoff from 2 to $62 \%$ and soil loss from 15 to $65 \%$ 
compared to untreated plots. At every location, runoff and soil loss reductions were observed. The amount of reduction was strongly related to the amount of manure added.

Many of the studies on runoff and erosion present mixed or unclear results; however, it does appear that most suggest less runoff and soil erosion when solid manures are land-applied. The results using lagoon effluent or slurries are less conclusive. Nevertheless, this is a substantial benefit that should be considered when determining the water quality impacts of land application of manures. Many studies look at the concentration of pollutants coming from fields where manure has been used. These concentrations may be higher, while if runoff is reduced, the total loads may be lower. Recently, increased emphasis has been placed on water quality models to help manage water resources. These models are being used to both assess water quality and allocate non-point source loads. Often these models adequately account for the land application of manure through increased nutrient availability, however, adjustments to runoff or soil erosion are rarely made. If modifications are not made, these models may overestimate the impacts of manure on pollutant loads in surface runoff. Likewise, decreases in runoff may result in greater $\mathrm{N}$ leaching that could impact losses to groundwater and this should be studied in greater detail.

\section{Manure Application Can Sequester Carbon}

Global climate change is driven by increased emissions of carbon dioxide $\left(\mathrm{CO}_{2}\right)$. The terrestrial pool of $\mathrm{C}$ is dominated by organic $\mathrm{C}$ in soil (IPCC, 2000). Fixation of $\mathrm{CO}_{2}$ from the atmosphere into plant biomass via photosynthesis drives the $\mathrm{C}$ cycle. Consumption of plant tissue by animals ultimately leads to a partitioning of $\mathrm{C}$ into animal biomass, $\mathrm{CO}_{2}$ respired by animals, and fecal deposition of $\mathrm{C}$ in unutilized byproducts. Animal manures in modern, confined agricultural systems are collected to avoid stockpiles and often applied to cropland or grazing land to replenish soil fertility. The fate of animal manures in soil depends upon the environmental conditions, primarily temperature and precipitation, as well as tillage, handling procedures, and the method and timing of application. Animal manures are eventually decomposed by soil microorganisms and may contribute to the pool of SOM, if stabilized biochemically or biophysically. Land application of animal manures could help mitigate potentially negative consequences of rising atmospheric $\mathrm{CO}_{2}$ on the global climate by contributing to greater sequestration of C in soil (CAST, 1992).

From a whole-farm simulation of the relative contributions of various agricultural components to soil organic C in Ontario, Beauchamp and Voroney (1994) concluded “....manure contributes a relatively small proportion of the $\mathrm{C}$ to soil compared to crop roots and residue, especially in swine systems, unless straw bedding is included." The small contribution of manure to soil organic C is supported by a study in Georgia, where poultry litter applied at rates between 4.5 and $26.9 \mathrm{~kg} \cdot \mathrm{m}^{-2} \mathrm{yr}^{-1}$ for two years resulted in a decline in organic matter from loss on ignition and no change in total $\mathrm{N}$ (Jackson et al., 1977). However, this interpretation is not supported by several other studies. Longterm data from a maize-bean rotation in Kenya with application of cattle manure increased soil organic $\mathrm{C}$ an average of $0.21 \mathrm{~kg} \cdot \mathrm{m}^{-2}$, while crop stover retention increased soil organic $\mathrm{C}$ an average of $0.11 \mathrm{~kg} \cdot \mathrm{m}^{-2}$ during 18 years without inorganic fertilization (Kapkiyai et al., 1999). As a percentage of $\mathrm{C}$ applied in manure, 5 to $12 \%$ was retained as soil organic $\mathrm{C}$, suggesting that significant soil $\mathrm{C}$ sequestration (i.e., 10 to $23 \mathrm{~g}^{\cdot} \mathrm{m}^{-2} \cdot \mathrm{yr}^{-1}$ ) is possible in the humid tropics with repeated and longterm application. The rate of soil organic $C$ sequestration with cattle manure $\left(20\right.$ to $22 \mathrm{~g}^{\cdot} \mathrm{m}^{-2} \cdot \mathrm{yr}^{-1}$; $\sim 10 \%$ retention of applied C) was similar in a cotton-guinea corn-groundnut rotation conducted for 45 years under the warm-moist climate in Nigeria (Agbenin and Goladi, 1997). In Georgia, soil organic $\mathrm{C}$ sequestration due to five years of poultry litter applied to bermudagrass pasture was $26 \pm 55$ $\mathrm{g} \cdot \mathrm{m}^{-2} \cdot \mathrm{yr}^{-1}(14 \pm 30 \%$ retention of applied C) under various harvest strategies (Franzluebbers et al., 2001). In Alabama, tall fescue pastures supplied with poultry litter for $21 \pm 4$ years sequestered soil organic $\mathrm{C}$ at a rate of approximately $30 \mathrm{~g}^{\cdot} \mathrm{m}^{-2} \cdot \mathrm{yr}^{-1}$ (8\% retention of applied C) (Kingery et al., 1994).

In the warm, semiarid region of India, application of farmyard manure to a pearl millet-wheat cropping system for 20 years resulted in a sequestration rate of 5,4 , and $3 \%$ of applied manure $\mathrm{C}$ at dry-matter rates of $1.5,3.0$, and $4.5 \mathrm{~kg} \cdot \mathrm{m}^{-2} \cdot \mathrm{yr}^{-1}$ (Gupta et al., 1992). The quantity of soil organic C accumulated in these systems increased with application of inorganic fertilizers, which may have further stimulated plant productivity and water uptake to slow decomposition. The rate of soil organic $\mathrm{C}$ sequestration on an area basis was between 21 and $54 \mathrm{~g}^{\cdot} \mathrm{m}^{-2} \cdot \mathrm{yr}^{-1}$, with greater values at 
higher application rates. At the end of 22 years of cattle manure application to a soil in Italy, soil organic $\mathrm{C}$ was 53 to $66 \%$ greater, equivalent to a soil organic $\mathrm{C}$ sequestration rate of $20 \mathrm{~g} \cdot \mathrm{m}^{-2} \cdot \mathrm{yr}^{-1}$ to a depth of $10 \mathrm{~cm}$ (Govi et al., 1992).

At the long-term experiment on Sanborn Field in Missouri, manure application resulted in soil organic $\mathrm{C}$ sequestration rate that averaged $33 \mathrm{~g}^{\cdot} \mathrm{m}^{-2} \cdot \mathrm{yr}^{-1}$ greater than with inorganic fertilizer under wheat and $53 \mathrm{~g}^{\cdot} \mathrm{m}^{-2} \cdot \mathrm{yr}^{-1}$ greater than with inorganic fertilizer under maize (Buyanovsky and Wagner, 1998). During 56 years of continuous manure application in eastern Oregon, soil organic C to a depth of $20 \mathrm{~cm}$ was $36 \%$ greater than with inorganic fertilization, equivalent to a soil organic $\mathrm{C}$ sequestration rate of $19 \mathrm{~g}^{\cdot} \mathrm{m}^{-2} \cdot \mathrm{yr}^{-1}(\sim 23 \%$ retention of applied C) (Collins et al., 1992). At the end of 4 years of poultry litter application on a sandy soil in England, the quantity of $\mathrm{C}$ retained as SOM was $48 \%$ of that applied, equivalent to a soil C sequestration rate of $102 \mathrm{~g}^{\cdot} \mathrm{m}^{-2} \cdot \mathrm{yr}^{-1}$ (Bhogal and Shepherd, 1997). With 135 years of continuous farmyard manure application in England, soil organic C sequestration was equivalent to $50 \mathrm{~g} \cdot \mathrm{m}^{-2} \cdot \mathrm{yr}^{-1}$ (17\% retention of applied C) (Webster and Goulding, 1989).

In the cold, semiarid region of Alberta, cattle manure applied to cropland at selected rates for 11 years nearly doubled soil organic $\mathrm{C}$ of the $0-15-\mathrm{cm}$ depth under dryland conditions and more than doubled soil organic C under irrigated conditions (Sommerfeldt et al., 1988). The rate of soil organic $\mathrm{C}$ sequestration in this study was predominantly a function of the quantity of manure applied, where $C$ retention rates were $32 \pm 4 \%$ of applied $C$, irrespective of water management (Chang et al., 1991). Calculated rates of soil organic $C$ sequestration were 164,309 , and $400 \mathrm{~g}^{\cdot} \mathrm{m}^{-2} \cdot \mathrm{yr}^{-1}$ when manure was applied at 3,6 , and $9 \mathrm{~kg} \cdot \mathrm{m}^{-2} \cdot \mathrm{yr}^{-1}$, respectively. In northern Alberta, farmyard manure applied to an 8-year rotation resulted in a relative soil organic C sequestration rate of 40 to $90 \mathrm{~g} \mathrm{~m}^{-2}$ $\cdot \mathrm{yr}^{-1}$ compared with a continuous grain system with inorganic fertilizer (Wani et al., 1994).

In the cold, moist climate of Quebec, cattle manure applied to corn grown for silage during 10 years resulted in 7 to $10 \%$ retention of applied $\mathrm{C}$ in soil, which was equivalent to soil organic $\mathrm{C}$ sequestration rates of 146 and $223 \mathrm{~g}^{\cdot} \mathrm{m}^{-2} \cdot \mathrm{yr}^{-1}$ at manure application rates of 4 and $8 \mathrm{~kg} \cdot \mathrm{m}^{-2} \cdot \mathrm{yr}^{-1}$ (Angers and N'Dayegamiye, 1991). In Ontario, a maize cropping system supplied with cattle manure sequestered soil organic $\mathrm{C}$ at a rate of $122 \mathrm{~g}^{\cdot} \mathrm{m}^{-2} \cdot \mathrm{yr}^{-1}$ to a depth of $20 \mathrm{~cm}$ (Liang and Mackenzie, 1992). From a long-term crop rotation experiment with 18 years of manure application in Quebec, approximately half of the soil organic C sequestration (56 to $90 \mathrm{~g}^{\cdot} \mathrm{m}^{-2} \cdot \mathrm{yr}^{-1}$ ) was found in macroaggregates and half in microaggregates, suggesting that $C$ supplied with manure to tilled soils can be physically protected within water-stable aggregates (Aoyama et al., 1999). Manure application to soil for 60 years in Denmark resulted in a soil organic C sequestration rate of $15 \mathrm{~g} \cdot \mathrm{m}^{-2}$ . $\mathrm{yr}^{-1}$, with two-thirds of the increase in the clay fraction and essentially no increase in the sand fraction (Christensen, 1988). In contrast, $60 \%$ of the $\mathrm{C}$ sequestered with manure application in Quebec was in the silt fraction and equal quantities of remaining $\mathrm{C}$ in the clay and sand fractions (Angers and N'Dayegamiye, 1991).

In general, soil organic $\mathrm{C}$ sequestration on a land area basis appears to be greater with an increased rate of manure application (Sommerfeldt et al., 1988; Gupta et al., 1992). However, high nutrient loading could pose environmental threats to water quality. Climatic regime is another important variable that appears to affect potential retention of applied $\mathrm{C}$ in soil. Thermic regions tended to have lower $C$ retention rates from manure $(7 \pm 5 \%)$ than temperate or frigid regions $(23 \pm 15 \%)$. Higher temperature would be expected to decompose manure more completely based on thermodynamic mechanisms that control soil microbial activity. Higher moisture would also be expected to accelerate decomposition of applied $\mathrm{C}$ to soil, yet $\mathrm{C}$ retention rates in moist regions $(8 \pm 4 \%)$ did not vary significantly from dry regions $(11 \pm 14 \%)$.

Manure Impacts Emissions of Methane and Nitrous Oxide

Climate forcing potential is a function of radiative forcing (i.e., the expected effect from the addition of a unit of gas on the radiation balance of the earth), mean lifetime (i.e., how long the forcing by a unit of gas is expected to continue), and emissions (i.e., total quantity of gas emitted). Of the three main gases that are influenced by land management and that are responsible for the potential greenhouse effect, carbon dioxide $\left(\mathrm{CO}_{2}\right)$ has the greatest climate forcing potential $(57 \%)$, while methane $\left(\mathrm{CH}_{4}\right)$ and nitrous oxide $\left(\mathrm{N}_{2} \mathrm{O}\right)$ account for $27 \%$ and $16 \%$ respectively (CAST, 1992). Methane and $\mathrm{N}_{2} \mathrm{O}$ emissions on a global scale are only 2 and $0.1 \%$ of those of $\mathrm{CO}_{2}$, but since they 
have 58 and 206 times greater radiative forcing potential, they are of significance to potential climate change issues. A significant portion of $\mathrm{CH}_{4}$ emitted to the atmosphere can be sequestered by aerobic soils. Thus, land application of manure could decrease significantly the net quantity of $\mathrm{CH}_{4}$ emitted to the atmosphere compared with stockpiling or long-term lagoon storage of manure.

Methane is emitted biologically to the atmosphere via methanogenic bacteria living in anaerobic soils, the rumen of cattle and sheep, and the intestinal tract of termites. Livestock production of $\mathrm{CH}_{4}$ (i.e., both from enteric fermentation and from animal waste storage) is estimated to be 20 to $34 \%$ of all $\mathrm{CH}_{4}$ produced globally (CAST, 1992; IPCC, 2000). The fraction of $\mathrm{C}$ in feedstuffs converted to $\mathrm{CH}_{4}$ in high-quality grain diets is less than in low-quality grass diets (Harper et al., 1999). However, how manure is handled could have major significance on the net quantity of $\mathrm{CH}_{4}$ emitted to the atmosphere from livestock. It remains unclear what the net emission rate would be from cattle fed on pastures (i.e., higher enteric release of $\mathrm{CH}_{4}$, but lower manure release of $\mathrm{CH}_{4}$ ) compared with cattle managed in confinement (i.e., lower enteric release of $\mathrm{CH}_{4}$, but higher manure release of $\left.\mathrm{CH}_{4}\right)$.

Nitrous oxide is emitted to the atmosphere primarily through the process of denitrification occurring in soil. The process of denitrification emits both $\mathrm{N}_{2}$ and $\mathrm{N}_{2} \mathrm{O}$, the former being a harmless gas that dominates the atmosphere and the latter being a radiatively active trace gas. The proportion of denitrification occurring as $\mathrm{N}_{2} \mathrm{O}$ increases under more aerobic conditions, with lower soil organic $\mathrm{C}$ content, soil pH, and soil temperature (Betlach and Tiedje, 1981).

Potential denitrification is strongly influenced by the water-soluble organic $\mathrm{C}$ content of manures, with slurries often containing greater concentrations of this important component than stacked or composted manures (Paul and Beauchamp, 1989). A soil with 3 times greater soil organic $\mathrm{C}$ due to long-term manure application resulted in $2.9 \mathrm{~g} \mathrm{~N} \cdot \mathrm{m}^{-2}$ lost via denitrification during the October-November period following barley harvest compared with $0.5 \mathrm{~g} \mathrm{~N} \cdot \mathrm{m}^{-2}$ lost in soil without manure application (Webster and Goulding, 1989). Despite differences in surface SOM, denitrification in the subsoil was unaffected by long-term application of farmyard manure because of the lack of biologically active $\mathrm{C}$ deep in the profile (Richards and Webster, 1999). However, on a sandy soil receiving poultry litter, $5 \%$ of the total applied $\mathrm{C}$ was leached as dissolved organic $\mathrm{C}$ at a depth of $1 \mathrm{~m}$, although the extent of denitrification was not determined (Bhogal and Shepherd, 1997).

Liquid manure provides readily oxidizable $\mathrm{C}$ and sufficient mineralizable $\mathrm{N}$ to activate the population of denitrifiers in soil. Comfort et al. (1990) found that most of the $\mathrm{N}_{2} \mathrm{O}$ emission occurred within the first 5 days following injection of manure into soil when soil $\mathrm{CO}_{2}$ evolution was greatest. Rainfall to saturate soil at 25 days following injection resulted in little emission of $\mathrm{N}_{2} \mathrm{O}$ despite the presence of significant nitrate, due to much lower microbial activity following exhaustion of readily decomposable C. Rapid, but relatively brief (i.e., within 30 days) emission of $\mathrm{N}_{2} \mathrm{O}$ occurred following swine slurry application to a soil with a history of manure application in Quebec (Rochette et al., 2000). Cumulative $\mathrm{N}_{2} \mathrm{O}-\mathrm{N}$ loss was $0.1 \mathrm{~g}^{\cdot} \mathrm{m}^{-2} \cdot \mathrm{yr}^{-1}(0.6 \%$ of total $\mathrm{N}$ applied) from inorganically fertilized soil, $0.2 \mathrm{~g}^{\cdot} \mathrm{m}^{-2} \cdot \mathrm{yr}^{-1}\left(1.2 \%\right.$ of total $\mathrm{N}$ applied) from soil receiving $6 \mathrm{~kg} \cdot \mathrm{m}^{-2} \cdot \mathrm{yr}^{-1}$ of swine slurry, and $0.4 \mathrm{~g}^{\cdot} \mathrm{m}^{-2} \cdot \mathrm{yr}^{-1}\left(1.7 \%\right.$ of total $\mathrm{N}$ applied) from soil receiving $12 \mathrm{~kg} \cdot \mathrm{m}^{-2} \cdot \mathrm{yr}^{-1}$ of swine slurry.

Lagoon storage of liquid animal waste could be a significant source of radiatively active trace gases, because of the anaerobic conditions and high organic $\mathrm{C}$ and nutrient contents. In a series of four lagoons designed to successively purify water from a swine production facility, the gas flux from Lagoon 1 (directly receiving animal waste) was dominated by $\mathrm{CH}_{4}(79 \%$ of total gas flux) with smaller quantities of $\mathrm{N}_{2}(15 \%)$ and $\mathrm{N}_{2} \mathrm{O}(<1 \%)$ (Harper et al., 2000). The gas flux from Lagoons 2,3 , and 4 was dominated by $\mathrm{N}_{2}(54,59$, and $69 \%$, respectively) with smaller quantities of $\mathrm{CH}_{4}\left(26,13\right.$, and $8 \%$, respectively) and $\mathrm{N}_{2} \mathrm{O}(<1,3$, and $18 \%$, respectively). Total gas flux (15.9, 2.1, 2.0, and $1.7 \mathrm{~g}^{\cdot} \mathrm{m}^{-2} \cdot \mathrm{d}^{-1}$ in Lagoons $1,2,3$, and 4, respectively) was inversely related to dissolved oxygen in the lagoons $\left(1,8,19\right.$, and $20 \mathrm{mg} \cdot \mathrm{L}^{-1}$ in Lagoons $1,2,3$, and 4, respectively).

Methane and nitrous oxide emissions are major trace gases evolved in liquid manure handling facilities. Engineering and biochemical strategies are needed to mitigate emissions of these gases to the atmosphere. 
Composting of Manure to Enhance Soil Organic C Sequestration

Composting of animal manure reduces volume, limits odors, stabilizes nutrients, kills weed seeds and pathogens, and reduces volatile organic compounds that can be detrimental to sensitive plants. Chemical changes during composting can affect $\mathrm{C}$ cycling processes. Composting of cattle manure doubled the proportion of humic substances from $35 \%$ before composting to $70 \%$ at the end of 100 days of composting (Inbar et al., 1990). The humic component that increased the most was humic acid (i.e., from $18 \%$ before composting to $45 \%$ after composting). Composting of feedlot cattle manure resulted in $51 \pm 9 \%$ loss of $\mathrm{C}$ (almost all through biological oxidation) and $31 \pm 12 \%$ loss of $\mathrm{N}\left(>90 \%\right.$ through $\mathrm{NH}_{3}$ volatilization) during three different years (Eghball et al., 1997).

Composting of poultry litter resulted in $16 \%$ loss of $\mathrm{C}$ via decomposition during 65 days (Mondini et al., 1996). The loss of $\mathrm{N}$ during composting was more substantial (49\%), largely due to $\mathrm{NH}_{3}$ volatilization during initial aeration and mixing of moist compost. Drying of poultry litter preserved much of the $\mathrm{C}$ and $\mathrm{N}$ of the original material ( $8 \%$ loss of $\mathrm{C}$, but $21 \%$ gain of $\mathrm{N}$ ), as well as increased the humic fraction with time although not as much as with composting (Mondini et al., 1996). The gain in $\mathrm{N}$ during drying of poultry litter was probably due to $\mathrm{NH}_{3}$ deposition from air circulated inside the poultry house.

Decomposition of animal manures in soil is dependent upon a number of factors including type of manure, feeding ration, animal age, living conditions of animal, and how manure is handled, as well as moisture and temperature conditions in the soil. The proportion of $\mathrm{C}$ in manure that decomposed during four weeks of incubation was $35 \pm 9 \%$ among six fresh manures, but was only $12 \pm 12 \%$ among four composted manures (Castellanos and Pratt, 1981). Similarly, the proportion of C in sheep manure that was mineralized to $\mathrm{CO}_{2}$ during four weeks was $\sim 18 \%$ when fresh, but only $\sim 13 \%$ when anaerobically stored (Sørensen and Jensen, 1995). However, during the subsequent eight weeks of incubation, no difference in decomposition occurred between fresh and anaerobically stored sheep manures. The proportion of $\mathrm{C}$ in manure that was mineralized during 10 weeks of aerobic incubation in soil was $23 \%$ from aerobically composted swine manure, $75 \%$ from fresh swine manure, and 105\% from anaerobically composted swine manure (Bernal and Kirchmann, 1992). Overall, these results suggest that $C$ in manures is lost during composting, and because of this loss, the remainder of $\mathrm{C}$ is less decomposable when applied to land.

\section{LIMITATIONS OF LAND APPLICATION}

There are several impediments that discourage greater use of manure nutrients in cropping systems including potential water quality problems associated with runoff from fields receiving manure, uncertainty associated with the nutrient availability in manure, and high transportation, application, and handling costs that discourage transport and greater utilization. Public perception and odor issues also impend greater use. In this section a brief review of each of these obstacles is presented as well as the current state of science in attempting to overcome these barriers.

\section{Excessive Application Results in Water Quality Impacts}

The EPA has identified agriculture as the leading source of pollution to rivers and streams (EPA, 1998). Animal agriculture, in particular, has been the focus of increasing regulatory pressure throughout the nation. As with any type of nutrient application to the land, there are environmental risks associated with land application of animal manures. Although land application of manures has many beneficial aspects, there are potentially detrimental effects for ground and surface waters if manure is not applied properly. The primary pollutants of concern are N, P, oxygen demand, pathogens, and hormones. Surface water is primarily affected through soluble contaminants in runoff or insoluble pollutants carried on soil particles during soil erosion events. Ground water can be contaminated from percolation, seepage, and direct infiltration.

When organic matter enters waterways, it is degraded by aerobic bacteria exerting biochemical oxygen demand (BOD) or chemical oxygen demand (COD). Most animal manures have BOD in excess of $20,000 \mathrm{mg} / \mathrm{l}$ and COD over $50,000 \mathrm{mg} / 1$. This compares with BOD and COD for domestic sewage in the range of $200 \mathrm{mg} / 1$ and $500 \mathrm{mg} / \mathrm{l}$ respectively. The high oxygen demand associated with runoff from livestock waste can rapidly deplete the water's natural dissolved oxygen supply. This results in fish kills and selectivity of other aquatic life (Tchobanoglous and Schroeder, 1987; Loehr, 1984). Organic matter also increases the total suspended solids in a stream, thus increasing 
the turbidity. The decomposition of organic matter contributes to color, taste, and odor problems in public water systems (Tchobanoglous, 1987).

Nutrients are the most common pollutant associated with animal waste. Several studies have documented the fact that watersheds with predominantly animal agriculture tend to have higher nutrient levels in their drainage systems. In fact, an EPA study of 928 watersheds across the nation (Omenik, 1977) found that mean concentrations of $\mathrm{N}$ and $\mathrm{P}$ in streams draining agricultural lands were nearly nine times higher than streams draining forested areas. Nitrogen and phosphorous compounds are needed for cellular growth; however, excessive amounts in surface waters result in eutrophication, algal blooms, and fish kills (Loehr, 1984).

Application of manures to crops or grasses at rates that exceed plant requirements for $\mathrm{N}$ can result in leaching of nitrate to ground water. For example, in Sussex County, Delaware, which produces more chickens than any other county in the U.S., there is a large area where ground water is contaminated by nitrate (Andres, 1995). Seepage from unlined lagoons can also cause ground water contamination by nitrate (Huffman and Westerman, 1995). Runoff from fields with recently applied, unincorporated manure can result in high levels of $\mathrm{N}$ in surface waters. This can cause eutrophication and low dissolved oxygen levels, especially in estuaries where $\mathrm{N}$ is more limiting than $\mathrm{P}$ for algal growth. Also, ammonium at high concentrations can cause a direct toxicity to fish (Frick et al., 1998).

While both $\mathrm{N}$ and $\mathrm{P}$ contribute to eutrophication, $\mathrm{P}$ is the primary agent in freshwater eutrophication. So in most cases, controlling eutrophication requires reducing $\mathrm{P}$ inputs to surface waters. Soil $\mathrm{P}$ exists in a number of mineral and organic forms, but most of it is adsorbed to iron and $\mathrm{Al}$ oxides (Sharpley and Sheffield, 2000). These oxides create a large, but not unlimited, number of adsorption sites for P. When adsorption sites are saturated, there is a potential for increased P dissolved in the soil water. This dissolved $\mathrm{P}$ is available to plants, and susceptible to runoff. As manure and fertilizers are added to soil, P levels at the soil surface increase sharply, but there is typically little increase the subsoil due to $\mathrm{P}$ adsorption. In very sandy soils that are low in iron and $\mathrm{Al}$ oxides, $\mathrm{P}$ can move into the subsoil or shallow groundwater. Ground water is not affected by $\mathrm{P}$ because of the absence of algae. Only when ground water returns quickly to a stream, river, or lake, is P leaching to ground water a concern (Sims et al., 1998).

In recent years, research has shown that the concentration of $\mathrm{P}$ in runoff from agricultural fields becomes greater as the P content in the topsoil increases (Pote et al., 1996). This is partly due to soil particles with high concentrations of adsorbed $\mathrm{P}$ being washed off the field through natural soil erosion processes. However, even in grass fields, where there is little erosion, dissolved P concentrations in runoff increase with soil test $\mathrm{P}$. P is cycled from roots to aboveground parts of the plant and redeposited in crop residues on the soil surface. When rain occurs there is a thin layer of water near the surface that mixes with the soil water and can run off. If the concentration of $\mathrm{P}$ in the soil water is high (because most of the adsorption sites near the surface are filled with P), then the concentration in the runoff water will also be high.

Soil P levels at the surface are unlikely to reach concentrations that will cause environmentally harmful concentrations in runoff unless manures are being used. Even though farmers have been encouraged to increase soil $\mathrm{P}$ levels in the past, the cost of fertilizers usually discourages overapplication of $\mathrm{P}$. Manure presents a special problem because the N-to-P ratio in manure is lower than that needed by crops. In most crop tissues, there are about $10 \mathrm{lb}$ of $\mathrm{N}$ for every $\mathrm{lb}$ of $\mathrm{P}$, or a ratio of 10 to 1, but manure usually has a much lower ratio. For example, a typical sample of swine anaerobic lagoon slurry would have $128 \mathrm{lbs}$ of total $\mathrm{N}$ and $22 \mathrm{lbs}$ of P per acre-inch of lagoon effluent (Barker et al., 1994). Since only about half of the manure $\mathrm{N}$ is available to plants (due to gaseous and other losses), the true ratio of N-to-P is about 3 to 1 . As a result of the low N-to-P ratio in manure, residual $\mathrm{P}$ builds up to environmentally harmful levels in fields that receive repeated applications.

Dry manures present a special additional problem when they are applied to grass fields and not incorporated. Under these circumstances, there is very little contact between the manure $\mathrm{P}$ and the soil. Rainwater mixing directly with the manure can cause a high concentration of dissolved $\mathrm{P}$ in the runoff. Some of the adsorbed organic $\mathrm{P}$ is transported by runoff as the manure is eroded from the site. Research has shown that runoff $\mathrm{P}$ concentrations are unrelated to soil $\mathrm{P}$ in these situations. 
Runoff P concentrations can be quite high ( $>25 \mathrm{mg} / \mathrm{L})$ when runoff occurs within a few weeks of manure application (Kuykendall et al., 1999).

Compared to $\mathrm{N}$ and $\mathrm{P}$, much less research has been done on bacteria and other pathogens in manures and their impact on water quality. Microorganisms occurring naturally in livestock waste can contaminate surface waters making them unfit for consumption, recreational, and industrial use. Pathogenic organisms in wastes may survive for days in surface waters depending upon environmental conditions. Factors affecting microbial survival include $\mathrm{pH}$, temperature, nutrient supply, competition with other organisms, ability to form spores, and resistance to inhibitors. The ability of pathogenic organisms to cause disease depends upon their concentration, virulence, ingestion and resistance (Loehr, 1984). The standard indicator organism for bacteria is fecal coliform (FC), which is harmless to humans but indicates the presence of fecal matter and other potentially harmful bacteria and viruses. Concentrations of FC in fresh manures are typically on the order of $10^{6}$ CFUs per gram (Barker et al., 1994). A number of studies have measured FC concentrations in runoff or in streams from agricultural areas. The concentrations were usually between $10^{3}$ and $10^{6}$ CFUs per $100 \mathrm{~mL}$ of water (Edwards and Daniels, 1994; Thelin and Gifford, 1983; Doran and Linn, 1979; Jawson et al., 1982; Edwards et al., 1997; Cook et al., 1998; Stephenson and Street, 1978; Tiedemann et al., 1988; Gary et al., 1983). Bacterial decay is caused by extremes in temperature, drying, and sunlight. Decay can generally be described with an exponential decay equation and reported half-lives are relatively short, ranging from one to four and a half days (Crane et al., 1980; Crane and Moore, 1986). A more in-depth review of pathogen-related issues associated with manure can be found in Strauch and Ballarini (1994) and the white paper on pathogens in this volume (p. 611).

Hormones such as estrogen and testosterone are present at relatively high concentrations in manures, especially poultry manure (Shore et al., 1995). These, along with other similar synthetic chemicals, are called endocrine disrupters and high levels in streams and drinking water are thought to cause a number of biological development abnormalities including sterility. Nichols et al. (1997) measured levels of estradiol (the most potent form of estrogen) in runoff from plots receiving different rates of poultry litter using a rainfall simulator immediately after application and 7 days after application. Estradiol increased linearly with application rate. Concentrations after 7 days were much lower than on first day but still above the control. Finlay-Moore et al. (2000) measured estradiol in runoff caused by natural rainfall from fields receiving poultry litter. Runoff concentrations were between 20 and 2,530 $\mathrm{ng} / \mathrm{L}$, depending on the rate of application and the time since application. Peterson et al. (2000) measured estradiol concentrations between 6 and $66 \mathrm{ng} / \mathrm{L}$ in spring water draining from an area in Arkansas where poultry litter had been applied to fields. Concentrations above $25 \mathrm{ng} / \mathrm{L}$ are thought to have an impact on stream biota.

It is generally accepted that the principal ways to reduce risks associated with land application involve appropriate application rate, timing, and location. These issues are commonly addressed through nutrient management planning. Even under ideal conditions with a well-planned system, there is still a significant risk of losses to the environment. Agricultural systems leak and elimination of non-point source impacts is practically impossible. Therefore, secondary treatment or preventative systems should also be incorporated into the design of all land application systems regardless of the choice of nutrient source.

\section{Nutrient Management Planning to Reduce Impacts}

The determination of application rates that provide crops with sufficient nutrients without having adverse environmental effects is one of the most critical land application issues. This is commonly accomplished through the development of nutrient management plans (NMPs). Studies have shown that the best method of avoiding groundwater and surface water contamination and possible crop damage is to limit applied manure to the amount required by the crop (CAST, 1996). This means that the total crop requirement, the nutrient pool in the soil, and the nutrient content of the manure must all be considered. Crop nutrient requirements are generally well-known and can be obtained from a variety of sources. To apply the amount of manure to meet the nutritional requirements of the crop without applying excessive amounts that could be lost to the environment, producers need a measure of the amount of nutrients in their soil and manure. The nutrient content of the soil can be determined through soil testing. The quantity and characteristics of livestock or poultry waste are highly variable and differ significantly from the initial values for manure excreted by the animal to the time of land application. Therefore, manure analysis is required. 
Nutrients applied from animal manure should match the needs of the crop, but the ratios of N, P, $\mathrm{K}$, and the various micronutrients excreted by animals are generally different from crop requirements. Not only does this present problems for the development of application rate recommendations, but it also produces nutrient imbalances in the soils and crops that receive animal manures (See the white papers on phosphorus issues and soil remediation in this volume.) Plans can be based on the $\mathrm{N}$ or $\mathrm{P}$ content of the manure, depending on which nutrient has the greater impact on receiving waters. P-based NMPs will also control $\mathrm{N}$ since they call for much lower application rates. Another way to reduce the $\mathrm{P}$ content in manure is to alter the feed ration by making the $\mathrm{P}$ more digestible through the use of phytase or new corn hybrids with a highly digestible form of $\mathrm{P}$ (Ertl et al., 1998). Alum can also be used to immobilize P in manure (Moore and Miller, 1994). The long-term solution to excess $\mathrm{P}$ is to return to a regional balance where locally grown grain is fed to livestock and the manure P returned to the grain fields. Ideally, the value of animal manures could be maximized if each individual nutrient could be separated and removed from the waste mixture and crop and soil specific fertilizer mixtures could then be reformulated.

By reducing application rates through the use of NMPs, concentrations of FC and hormones are also reduced. Another way to reduce FC and perhaps hormones is by storing manure for a short period of time before applying it to fields. Hartel et al. (2000) found that FC in fresh broiler litter ranged from $<10$ to $10^{8}$ cols $/ \mathrm{g}$ ( $45 \%$ of samples had $\mathrm{FC}$ below the detection level of $10 \mathrm{cols} / \mathrm{g}$ ). By comparison, all stacked samples had FC concentrations less than the detection level. Because of the relatively high die-off rates of bacteria when manure is applied to fields, direct deposition of manure in streams by cattle can have a disproportionately large effect on stream FC concentrations. Therefore, fencing cattle out of streams may substantially reduce FC contamination (Cook et al., 1998).

Proper and timely application of animal manure is important in reducing nutrient losses and pollution potential. Time and method of application depend on climate, cropping system, management system, source and form of animal waste, and equipment and labor availability (Gilbertson et al., 1979). Animal waste should only be applied at periods when the nutrients can be used. For crops the best time is immediately prior to planting, while immediately following each hay harvest or grazing cycle usually results in optimal use in forage systems. More frequent applications of smaller amounts can increase plant uptake and use while decreasing the amount lost to the environment. The method of application is dependent on the form of the manure. Whatever form, the keys to successful application are that a known amount is applied at the proper location with minimal losses. All manure application systems should be calibrated regularly. Incorporation is also a recommended practice as it reduces odors, maximizes nutrient availability, and limits nutrient losses. Injection systems reduce odors and losses of ammonia and may be the most efficient application method; however, they are not used extensively because of the difficulty in injecting solid materials. Considerable improvements could be made in both the application equipment and methods.

The USDA/EPA Unified National Strategy for Animal Feeding (USDA-EPA, 1999) establishes a national performance expectation that all AFOs should develop and implement technically sound, economically feasible Comprehensive Nutrient Management Plans (CNMPs). It goes on to reference the USDA Natural Resources Conservation Service Technical Guidance on Comprehensive Nutrient Management Plans (USDA, 2000) as the primary technical reference on CNMPs. Furthermore, nutrient management is recognized as the internationally accepted strategy to address field nutrient losses (Beegle et al., 2000). Traditionally, nutrient management has been concerned with optimizing the economic return from nutrients used for crop production. Land Grant Universities and crop consultants have been developing and using these types of NMPs for years. Today, the agronomic and economic requirements of nutrient management remain central, but in addition, the process is being expanded to include all of the potential environmental impacts of nutrients in the entire farm operation (Beegle et al., 2000).

As the concept of nutrient management planning is evolving, there is considerable confusion over exactly what it entails. Part of this confusion is due to the conflicting goals of the agencies involved in developing and implementing nutrient management plans. The NRCS, a conservation planning organization, states that a CNMP is a grouping of conservation practices and management activities which, when implemented as part of a conservation system, will help ensure that both 
production and natural resource goals are achieved (USDA, 2000). They define CNMPs to include not only land application but also manure and wastewater handling and storage, land treatment including conservation practices addressing soil erosion and surface runoff, record keeping, feed management, and even off-farm utilization. Meanwhile, the U.S. EPA has proposed to include a Permit Nutrient Plan (PNP) as part of their regulations on animal feeding operations (U.S. EPA, 2001 a). The stated goals for these plans are to protect water quality and the environment by insuring that a confined animal feeding operation (CAFO) meets effluent discharge limitations and other requirements of the Clean Water Act permits. Some of these standards go beyond those required in CNMPs but the requirements generally do not include the depth associated with CNMPs. In fact, the EPA defines a PNP as a subset of a CNMP (U.S. EPA, 2001b). Both CNMPs and PNPs go well beyond land application and expand the role of nutrient management planning to tracking nutrient flows throughout the animal feeding operation. Many of the issues that were covered under State regulations in the permits issued to AFOs are now being addressed through nutrient management plans making them more like a permit than a management plan. This increases both the cost and complexity of these plans while there is little evidence that it will decrease nutrient losses to the environment.

Few studies have documented the effectiveness of nutrient management plans and some studies suggest that it will be difficult for farmers to reduce environmental impacts even with well developed plans (Hutson et al., 1998). Often nutrient management plans do result in benefits for farmers and society, especially as an educational process; however, implementation has not been as great as desired (Beegle et al., 2000). Nowak et al. (1998) in a study of over 1,150 farms in Wisconsin found that very few farmers actually take nutrient credit for manure application and few recognize the economic or soil quality benefits derived from proper nutrient management. They found that, on average, these farmers could save $\$ 38.86$ per ha on commercial fertilizer through better utilization of on-farm nutrients. They concluded that a primary reason for this failure to credit manure nutrients was the complexity involved in the determination of these values and that only through the reduction or elimination of these constraints would proper nutrient management be realized. Jackson et al. (2000) looked at ten CAFOs in Iowa and found that operators minimized the area required for manure utilization in plans by underestimating manure $\mathrm{N}$ content, projecting above-average crop yields, and applying manure to soybeans. Parsons et al. (1998) conducted an in-depth modeling study to examine the economic and environmental impact of nutrient management on dairy and poultry farms in Virginia. Their analysis included three differing approaches: requiring all manure to be incorporated and $\mathrm{N}$ - and P-based application rates. They found that requiring incorporation was not economically or environmentally sound, that an N-based strategy would significantly reduce $\mathrm{N}$ losses at little cost to the farmers while reducing $\mathrm{P}$ losses only 3 to $15 \%$, and that the Pbased strategy would provide the best environmental benefit but also come with a substantial cost to the farmer. In a similar study, Van Dyke et al. (1999) found that average N and P losses were reduced $23-45 \%$ and $23-66 \%$ while net income increased by $\$ 395$ to $\$ 4,593$ on three Virginia farms. Much of this economic data is dependent on assumptions concerning manure markets that are not well quantified.

A NMP must be practical to be effective (Beegle et al., 2000). For example, calculated manure application rates must be achievable in the field and the farmer must understand the principles involved in determining the application rate. As these plans become more comprehensive in nature, often requiring a "certified specialist" to develop them, they often become less practical and tend to become more difficult to practically implement. In fact, the bottom line to most producers is the determination of a recommended application rate. A slightly imperfect, less comprehensive, but practical plan will almost always provide greater results than a perfect one that is not practical to implement. More research is needed to determine the effectiveness of NMPs at addressing water quality concerns and the key components that should be addressed in these plans. This should be done in conjunction with detailed cost-benefit analysis to determine key components.

There are also substantial extension needs to establish planning processes and to educate producers on the need for and benefits of NMPs. Currently, there is very little infrastructure in place and the impacts of requiring plans before it is available to farmers would lead to considerable confusion and misinformation (Meyer and Mullinax, 1999). It could also lead to frustration and reluctance on the part of smaller operators who are being encouraged to voluntarily develop plans. Some com- 
puter tools have been developed to assist farmers in developing nutrient management plans; however, most of these focus on obtaining proper and economical manure application rates and not developing a comprehensive plan for the farm (Levins et al., 1996; Thompson et al., 1997). Computer tools and decision support systems will be needed to develop CNMPs or PNPs on a national basis. These on-farm tools should attempt to minimize input data requirements and should serve as both development tools and educational aids for nutrient management plans.

Models should also be developed to evaluate manure management alternatives and farm policy. Due to the expense and labor intensivity of long-term field studies required to reliably quantify agricultural nonpoint source pollutants, computer models of nutrient management are needed to evaluate different management scenarios and application conditions (Sharpley and Meyer, 1994). These models should be developed at different levels. Research-type models that require extensive inputs should be developed to evaluate manure management alternatives for the development of best management practice recommendations and farm policy (Tim and Jolly, 1994; Gelata et al., 1994). However, a major limitation to these models is often the lack of detailed parameterization data on soil properties and climate, crop, and tillage information. There is also a need for on-farm type models that require less input data and can be used as educational tools by farm owners and operators. Recent developments in geographical information systems (GIS) and advanced interfaces could make many existing models more user friendly and help them to gain broader acceptance and use. GIS systems also have the potential to be used for targeting sensitive areas and for the development of nutrient management plans for smaller areas under site-specific or "precision" conditions.

\section{BMPs and Water Quality Protection}

There are a number of other best management practices (BMPs) that can be adopted to minimize the water quality impact of manure. Any practice that reduces the amount of soil erosion or runoff from a field positively impacts surface water while practices that minimize leaching should prevent groundwater contamination. Excessive runoff should be avoided on areas where manure has been applied. The principal elements affecting runoff are rainfall characteristics, soil factors, climate and land use. The total amount, timing, and intensity of rainfall influences the quantity of runoff that occurs from a given region. One of the most effective means of reducing runoff is to maintain high infiltration rates. Areas with a complete ground cover usually have high infiltration rates and are least susceptible to runoff. Conservation tillage, contouring and strip cropping, terraces, and vegetated waterways have all been used effectively to minimize runoff. Narrow grass hedges have also been employed to reduce runoff, control erosion, decrease nutrient transport, and provide wildlife habitat. The method and timing of manure application should be adjusted to reduce the amounts of constituents transported in runoff.

Regardless of how effectively agricultural systems are managed, they will impact non-point source water quality. Secondary treatment systems such as vegetative buffer zones, grass filter strips, riparian zones, and/or other vegetative filters can prevent nutrient and pathogen movement to surface waters. One of the most important BMPs is the use of grass filter strips and riparian buffers. Riparian buffers are very effective at reducing ground water $\mathrm{N}$ inputs to streams where ground water flow is restricted to shallow depths (Lowrance et al., 1995). The ideal stream-side buffer consists of an undisturbed forest zone next to the stream and a managed zone next to the field, which could consist of trees or a grass filter strip. Grass filter strips are very effective in filtering out $\mathrm{N}$ and $\mathrm{P}$ adsorbed to sediment because they slow down the flow of water and cause the sediment to settle out. They have less of an effect on the $\mathrm{P}$ dissolved in runoff. Contour filter strips also reduce FC concentrations (Coyne et al., 1995), but more research is needed in this area.

Secondary containment systems and diversions can also reduce water quality impacts. These types of systems consist of berms or ditches around application areas to keep clean water from coming into contact with manure or wetlands. Sedimentation basins and farm ponds that trap and treat contaminated runoff also serve as effective management practices. Ultimately, the goal of these systems should not be treatment, but should be a secondary system that insures that contaminated runoff does not directly enter surface water. The need for these types of systems is highly dependent on the receiving water body because secondary systems are not always economically justified. 
Studies addressing the cost-benefit and efficiency of these systems to the farm and comprehensive watershed scale are needed to aid in producer decisions and to help with TMDL modeling efforts. Research efforts should focus on developing technologies that use natural and modified drainage patterns to limit off-site transport of nutrients and the development of BMPs to synchronize nutrient availability from manure with crop nutrient needs. Tillage impacts on nutrient and pathogen loads should also be investigated as the trade-offs between nutrient distribution and nonpoint source loads are not clearly established. Educational programs and policies to inform and to encourage adoption of current conservation technologies and BMPs by farmers is also an immediate need.

For BMPs to be effective, they must be implemented as part of a total management system rather than individual practices because systems minimize the impact of the pollutant at several points: the source, the transport process, and the delivery (Osmond et al., 1995). Properly designed BMP systems must also be site specific and placed in the appropriate locations. Finally, since financial resources are limited, BMP implementation should be prioritized and cost-share money should only be used in those locations that will have the greatest impact. Successful adaptation of on-farm BMPs is highly dependent on education. Producers must understand the impact their practices will have on the environment and the mechanism that the BMP uses to reduce this impact. More research is also needed to document the effectiveness of specific BMPs.

While manure treatment is beyond the scope of this text, the environmental impacts of land applied manure are highly dependent on treatment. Most treatment processes reduce nutrient and pathogen loads and therefore impact the quality of runoff and leachate coming from fields where manure has been applied. Composting manure can reduce its impact on water quality. Most importantly, it will minimize, if not eliminate, bacterial contaminants. If excess $\mathrm{N}$ is a problem, composting will reduce available $\mathrm{N}$ levels due to ammonium volatilization and $\mathrm{N}$ transformations to less harmful organic forms. Unfortunately, composting reduces the available P content only slightly (due to the formation of stabilized organic forms) (Vervoort et al., 1998). The result is that following composting the N-to-P ratio is even lower than in fresh manure and more out of balance with crop requirements.

\section{Variability in Manure Nutrient Content Limits Greater Use}

Farmers often choose to use commercial sources of fertilizers instead of manure because of variability and uncertainty concerning the nutrient content of manure. The quantity and characteristics of livestock or poultry wastes are highly variable. They depend on the animal type, ration, manure management system, climate, storage system, and time and method of land application (Gilbertson et al., 1979). The amount and type of animal bedding can also influence the nutrient content. More accurate information is needed concerning the effects of modern rations, breeding, and manure management systems on the value of animal wastes. The nutrient composition of manure can vary widely depending on animal species (Barnett, 1994a; Millmier et al., 2000) and management (Rieck-Hinz et al., 1996; Patterson et al. 1998). For example, $\mathrm{P}$ concentration has been found to range from $6.0 \mathrm{~g} \mathrm{P} \mathrm{kg}^{-1}$ in dairy manure to $30.3 \mathrm{~g} \mathrm{P} \mathrm{kg}^{-1}$ in layer manure (Barnett (1994a). Similarly, $\mathrm{P}$ concentration in poultry litter has been found to vary from 8.0 to $25.8 \mathrm{~g} \mathrm{P} \mathrm{kg}^{-1}$ (mean $=14.3 \mathrm{~g} \mathrm{P}$ $\mathrm{kg}^{-1}$; Edwards et al., 1992), depending on management. Using these estimates, an application of $5,000 \mathrm{~kg}$ poultry litter ha ${ }^{-1}$ could provide 40 to $129 \mathrm{~kg} \mathrm{P} \mathrm{ha}^{-1}\left(\right.$ mean $\left.=71 \mathrm{~kg} \mathrm{P} \mathrm{ha}^{-1}\right)$. While $40 \mathrm{~kg} \mathrm{P}$ $\mathrm{ha}^{-1}$ would supply the $\mathrm{P}$ required by most crops, $129 \mathrm{~kg} \mathrm{P}^{-1}$ would result in an excessive application. This large difference indicates that it would be difficult to develop useful manure management plans based on average nutrient concentrations. Manure nutrient analysis is usually recommended to overcome this variability. Currently, most farmers must sample their manure regularly and often wait extended periods for test results. The development of inexpensive, on-farm nutrient tests would allow for testing at the time of application. For producers not testing their manure, educational and research emphasis should be placed on developing more site specific and detailed estimates of manure nutrient content as well as the economical and environmental effects of excessive application.

\section{Manure Sampling and Handling Limits Greater Use}

Obtaining representative manure samples presents unique challenges depending on the physical nature of the manure. In the case of dry manures (e.g. poultry litter, beef feedlot manure), one of the 
main challenges is to collect a representative sample from a material that may contain small fragments as well as large clumps. The ideal sample should contain small fragments and clumps in the same proportion in which they are present in the manure to be land applied. Furthermore, once the ideal sample is obtained, the whole sample should be ground to yield a homogeneous material from which to obtain a representative subsample for chemical analysis. Grinding presents challenges of its own because above a certain water content dry manures tend to cake during the grinding process. This problem leads to the need for drying before grinding, which in turn can lead to losses of $\mathrm{N}$ through ammonia volatilization (Gale et al., 1991). Several drying methods have been investigated in an effort to identify those that minimize $\mathrm{N}$ losses. In a study with poultry and other animal manures, Mahimairaja et al. (1990) found that overnight freezing, followed by freeze-drying for $3 \mathrm{~d}$, caused minimum losses of $\mathrm{N}$ when compared to air drying for $10 \mathrm{~d}$ at room temperature, oven drying at $105^{\circ} \mathrm{C}$ for $48 \mathrm{~h}$, and microwave oven drying at $700 \mathrm{~W}$ for $30 \mathrm{~min}$. In contrast, Wood and Hall (1991) found that freeze-drying poultry litter led to larger losses of total $\mathrm{N}$ than oven drying at $40^{\circ} \mathrm{C}$ for $3 \mathrm{~d}$ or microwave oven drying at $40^{\circ} \mathrm{C}$ for $30 \mathrm{~min}$. Clearly, additional work is needed on sampling and drying methods for dry manures.

In the case of wet manures (e.g. dairy, poultry, and swine slurries), one of the main sampling challenges is to obtain a representative sample from a manure slurry that has different liquid and solid phases. Because the nutrient concentration of manure slurries varies depending on the solid concentration (Odell et al., 1995; Campbell et al., 1997), the ideal sample should contain liquid and solid phases in the same proportion in which they are present in the slurry to be land applied. It would therefore be ideal to take the sample while the slurry is being stirred in the same way in which it will be stirred during transfer to the spreader. Once the sample is collected, homogenization before subsampling is needed to obtain a representative subsample for chemical analysis.

Problems inherent to the analysis of manure samples were described in the section on nutrient availability. Chemical methods are faster than biological methods, but they still need to be conducted in the laboratory and require several days to complete. One of the potential problems with methods that require several days is that available $\mathrm{N}$ concentration in manure can change between sampling and application (Odell et al., 1995). Consequently, the ideal method would allow a quick determination of available $\mathrm{N}$ in the field, just before the manure is applied. Rapid methods are currently available for determination of ammonium in manure slurries (Van Kessel et al., 2000), but are not available for measuring available $\mathrm{N}$ in dry manure. Additional research in this area is needed to develop rapid, accurate methods for testing dry manure in the field.

\section{Transportation and Handling Costs Limit Greater Use}

Most livestock farms (78 and 69\% for $\mathrm{N}$ and $\mathrm{P}$ respectively) have adequate land to apply manure at agronomic rates; however, the farms where this is not the case account for over half the nation's manure N and P (Gollehon et al., 2001). Where animal production is concentrated, the land base available for manure application is usually limited. Still, even in concentrated production areas, there is usually sufficient land available where it would be feasible to apply manure. About $20 \%$ of the nation's on-farm excess manure $\mathrm{N}$ is produced in counties with insufficient crop land acreage for land application at agronomic rates (Gollehon et al., 2001). In these situations, either transport to distant areas or alternative utilization strategies will be required.

The main barrier to increased transport of manure is the economics. The collection, transport, storage and handling of manure to and from the point of processing are all an economic concern. Freeze and Sommerfeldt (1985) found that manure from large feedlots that haul manure in singleaxle trucks or pull-type manure spreaders could only be economically hauled up to $15 \mathrm{~km}$. The economic hauling distance is inherently tied to moisture content as the cost of hauling increases with moisture content. For this reason, off-farm transport of dry poultry litter is relatively common while lagoon effluent is rarely moved away from the farm of origin. Little research emphasis is being placed on the concepts of materials handling and metering for animal manure, yet the economics of transporting the material to the point of use is often the greatest concern limiting the livestock producers from maximizing the use of this biomass resource (Gilbertson et al., 1984). Bosch and Napit (1992) found that export of poultry litter from surplus to deficit areas for use as a fertilizer in Virginia is often economically viable at larger scales; however, large scale transfers of poultry litter were not occurring. They suggested that the use of government subsidies to crop producers who 
purchase litter for use as a fertilizer would encourage more research in transport and increase the incentives for commercial firms to provide litter transfer services. Many European governments do provide subsidized transport cost for manure and these programs have generally resulted in greater use of animal waste (Conway and Pretty, 1991). Better integration of farms that produce crops and livestock and educational programs aimed at showing farmers the economic value of manure as a fertilizer are other methods of reducing transport costs. Separation, screening, condensing, and dewatering technologies could also be used to produce more transportable products; however, little research is being conducted in these areas.

\section{Public Perception and Odor Concerns Limit Greater Use}

Public perception of agriculture in general and land application of animal manure in particular is critical to continued acceptance of land application as the primary manure utilization strategy because it generally drives the regulatory process. Public concerns with animal manures can be broken into three major categories; water quality, air quality, and food quality. Land application of manures has the potential to negatively impact all three. The general public is dissociated from agriculture and the popular press often is their primary source of information. Many issues not directly related to land application, such as the changing scale of animal feeding operations, odor concerns of neighboring land owners, and atmospheric emissions from lagoons, are increasingly receiving negative press. Land application of other materials such as municipal biosolids are also generating concerns. Information on the scientific basis for land application, the environmental risks associated with it, and an open discussion of alternative technologies needs to be communicated to the general public in an easily understood manner so that they are equipped to have input on policy decisions.

Land application is also hindered in areas of urban and suburban populations by concerns about odors and flies. Air quality issues associated with land application of manure include off-site drift, ammonia emissions, and odor. Odor concerns are drawing increased attention as the urban/ suburban areas expand into traditional agricultural areas. Odor problems are the number one complaint against animal growers received by state and federal regulatory agencies (Moore et al., 1995). Odors are a persistent problem near feedlots, loafing areas, and fields receiving land applications of waste. Since a manure odor is the product of complex interactions of many individual odorous components, it is difficult to accurately characterize it in terms of quality or quantity. There are many technologies for reducing the odor associated with land application of manures (see associated white paper in this volume, p. 723). Odor control methods include treatment of manure, capture and treatment of emissions, increased odor dispersion, and diet modification (Sweeten, 1992). While research has documented many control strategies that can be effective in animal facilities, further efforts will be required to incorporate these ideas into land application systems. Odor suppressants, counteractants, masking agents and numerous chemicals have also been used in animal production to reduce odors. The results have often been less than satisfactory. Further research could refine technologies for reducing odor impacts.

Food quality impacts associated with land application have not received as much attention; however, there is a growing concern among consumers over food quality issues (Strauch and Ballarini, 1994). Organic production which usually depends on manure to maintain soil fertility, represents one of the fastest growing segments in agriculture today. This may lead to increases in the use of manure on food crops. The U.S. Food and Drug Administration recognizes that properly treated manure can be an effective and safe fertilizer; however, it cautions that growers should follow recommended agricultural practices for handling manure to minimize microbial hazards (USDA, 1998). Some of these practices include treatments to reduce pathogens and maximizing the time between application and harvest. Recommendations for avoiding disease transmission include steps to reduce disease susceptibility and careful handling and spreading of manure from animals at a high risk for infection, especially young calves (Pell, 1997). Many producers, food safety organizations, and the USDA organic standards encourage the use of a 60-day waiting period between manure application to food crops and harvest. More research is needed to develop application and treatment methods to reduce the risk of pathogen transfer to food crops and to verify the safety of these practices. This should be coupled with educational programs that document food safety to the consumer. 


\section{SUMMARY OF RESEARCH, EXTENSION AND POLICY NEEDS}

Land application of animal manure has been a cornerstone of animal agriculture. However, if used to its potential, manure could represent a much larger percentage of the total applied nutrients without concern for environmental degradation. Ultimately, in the pollution prevention hierarchy, utilization of manure nutrients on the farm as fertilizer input represents a more sustainable solution than other options such as off-site transfer, energy production, or disposal. Further research and extension efforts could lead to this increased use. The following sections summarize some of the most pressing research and extension needs identified in this paper.

Manure Impacts on Soil Quality and Crop Growth

- Research and educational programs focusing on quantification of the non-fertilizer value of manures is essential for greater utilization.

- More research should be conducted to demonstrate and place an economic value on the water quality benefits that manure offers in terms of reduced runoff and erosion.

- Studies that compare the agronomic qualities of different types of manure including composts are needed to demonstrate the value that processing choices have on soil and water quality.

- Studies to determine the long-term effects of manure application on soil physical, biological and chemical properties, on crop and animal productivity, and on adjacent ecosystems should be conducted.

- Research and extension projects focused on showing non-farm audiences that land application is safe, sustainable, and environmentally sound.

Manure and Carbon Sequestration

- Research to document the long-term effects of manure handling (e.g., composting, additives) and soil management (e.g., tillage, liming, irrigation, fertilization) interactions on carbon dioxide, methane, and nitrous oxide fluxes and soil organic $\mathrm{C}$ sequestration.

- Studies to determine if manure treatment practices to reduce $\mathrm{P}$ availability (i.e., alum, $\mathrm{Fe}$ oxides) affect the stability of $\mathrm{C}$ in manure.

- Research to determine the impact of increasing the stability of $\mathrm{C}$ in composts on potential soil organic $\mathrm{C}$ sequestration on a farm scale.

- Investigations to find economically viable crop rotations that could sequentially receive substantial nutrients from manure during high-nutrient-demanding crop phases, while preserving the $\mathrm{C}$ sequestration potential of manures and crop residues during other phases.

- Socio-economic studies to determine economic incentives necessary for producers to systematically implement agricultural practices to maximize the $\mathrm{C}$ sequestration potential in animal manures.

\section{Manure Distribution Issues}

- Research to develop methods to overcome the high transportation costs limiting the potential to transport to off farm areas is needed. This should include applied research into technology development and economic analysis of separation, screening, condensing, and dewatering technologies that could produce more transportable and valuable products.

- Quantifying the economic and agronomic effects of additives or blends with other materials could also result in greater utilization.

\section{Manure Nutrient Issues}

- Research to address problems encountered in collecting representative manure samples for nutrient analysis and determining the nutrient content of manures.

- Development of inexpensive, on-farm nutrient tests that would allow for testing at the time of application and more frequent and dependable test results.

- Research to improve our understanding and knowledge of mineralization rates and their effects on crop growth.

- Develop techniques to assess nutrient availability of manure in specific soil-crop-climate systems.

- Research that provides a better understanding of the effectiveness of different methods of manure application on crop nutrient uptake and utilization. Research should also address the de- 
velopment of application technologies with improved accuracy and precision or lower unit costs.

\section{Nutrient Management Planning}

- Determination of application rates that provide the crop with sufficient nutrients without having adverse environmental effects.

- Development of sustainable planning methodologies that take a systems approach combining manure and other fertilizers rather than concentrating on individual nutrients.

- Research is needed to determine the effectiveness of NMPs at addressing water quality concerns and the key components that should be addressed in these plans. This should be done in conjunction with detailed cost benefit analysis to determine key components.

- There is a need for on-farm decision support systems and environmental models that require little input data and can be used by non-scientific users in planning manure application strategies.

- There are also substantial extension needs to implement planning processes and to educate producers on the need for and benefits of NMPs.

\section{Other Water Quality Measures}

- Continuation of research associated with minimizing the potential for runoff and leaching under various management scenarios and development of BMPs to reduce nutrient losses from agricultural areas receiving manure.

- Research efforts should focus on developing technologies that use natural and modified drainage patterns to limit off-site transport of nutrients and identifying BMPs to synchronize nutrient availability from manure with crop nutrient needs.

- Determine the relationship between soil P and movement of soluble P to surface and shallow ground water and develop predictive tools to identify areas susceptible to P losses on a landscape.

- Tillage impacts on nutrient and pathogen loads should also be investigated as the trade-offs between nutrient distribution and non-point source loads are not clearly established.

- Studies addressing the cost-benefit and efficiency of these systems to the farm and comprehensive watershed scale are needed to aid in producer decisions and help with TMDL modeling efforts.

- Educational programs and policies to inform and to encourage adoption of current conservation technologies and BMPs by farmers is also an immediate need.

- With further research on rotational grazing/free range systems and improvements in forage genetics and production, extensive systems could become more economical for small to midsize producers.

\section{REFERENCES}

Agbenin, J.O. and J.T. Goladi. 1997. Carbon, nitrogen and phosphorus dynamics under continuous cultivation as influenced by farmyard manure and inorganic fertilizers in the savanna of northern Nigeria. Agriculture, Ecosystems and Environment 63:17-24.

Albiach, R., R. Canet, F. Pomares, and F. Ingelmo. 2001. Organic matter components and aggregate stability after application of different amendments to a horticultural soil. Bioresource Technology 76(2):125-129.

Andres, A.S. 1995. Nitrate loss via ground water flow, Coastal Sussex County, Delaware. In K. Steele (Ed). Animal waste and the land-water interface. Lewis Publishers. Boca Raton, FL. Pp. 69-76.

Angers, D.A. 1998. Water-stable aggregation of Quebec silty clay soils: some factors controlling its dynamics. Soil \& Tillage Research 47(1-2):91-96.

Angers, D.A. and A. N'Dayegamiye. 1991. Effects of manure application on carbon, nitrogen, and carbohydrate contents of a silt loam and its particle-size fractions. Biology and Fertility of Soils 11:79-82. 
Aoyama, M., D.A. Angers, A. N’Dayegamieye, and N. Bissonnette. 1999. Protected organic matter in water-stable aggregates as affected by mineral fertilizer and manure applications. Can. J. Soil Sci. 79(3):419-425.

Aryantha, I.P., R. Cross, and D.I. Guest. 2000. Suppression of Phytophthora cinnamomi in potting soil mixes amended with uncomposted and composted animal manures. Phytopathology 90(7):775-782.

Barker, J.C., J.P. Zublena, and C.R. Campbell. 1994. Agri-waste management: Livestock manure production and characterization in North Carolina. North Carolina Cooperative Extension Service. Raleigh, NC.

Barnett, G.M. 1994a. Phosphorus forms in animal manure. Bioresour. Technol. 19:139-148.

Barnett, G.M. 1994b. Manure P fractionation. Bioresour. Technol. 19:149-155.

Barrington, S.F. and C. A. Madramootoo, 1989. Investigating seal formation from manure infiltration into soils. Trans. ASAE 32(3):851-856.

Barthes, B., A. Albrecht, J. Asseline, G. De Noni, and E. Roose. 1999. Relationship between soil erodibility and topsoil aggregate stability or carbon content in a cultivated Mediterranean highland (Aveyron, France). Comm. in Soil Sci. and Plant Anal. 30(13-14):1929-1938.

Bates, T. and E. Gagon. 1981. Nutrient content of manure. University of Guelph, Ontario, Canada.

Beauchamp, E.G. 1983. Response of corn to nitrogen in preplant and sidedress applications of liquid dairy cattle manure. Can. J. Soil Sci. 63:377-386.

Beauchamp, E.G. 1986. Availability of nitrogen from three manures to corn in the field. Can. J. Soil Sci. 66:713-720.

Beauchamp, E.G. and R.P. Voroney. 1994. Crop carbon contribution to the soil with different cropping and livestock systems. J. of Soil and Water Cons. 49:205-209.

Beegle, D.B., O.T. Carton, and J.S. Bailey, 2000. Nutrient management planning: justification, theory, practice. J. Environ. Qual. 29:72-79.

Benoit, P., E. Barriuso, S. Hovot, and R. Calvert. 1996. Influence of the nature of soil organic matter on the sorption-desorption of 4-chlorophenol, 2,4-dichlorophenol and the herbicide 2,4dichlorophenoxyacetic acid (2,4-D). European J. Soil Sci. 47(4):567-578.

Bernal, M.P. and H. Kirchmann. 1992. Carbon and nitrogen mineralization and ammonia volatilization from fresh, aerobically and anaerobically treated pig manure during incubation with soil. Biology and Fertility of Soils 13:135-141.

Betlach, M.R. and J.M. Tiedje. 1981. Kinetic explanation for accumulation of nitrite, nitric oxide, and nitrous oxide during bacterial denitrification. Applied and Environmental Microbiology 42:1074-1084.

Bhogal, A. and M. Shepherd. 1997. Effect of poultry manure on the leaching of carbon from a sandy soil as a potential substrate for denitrification in the subsoil. Journal of the Science of Food and Agriculture 74:313-322.

Bohlen, P.J. and C.A. Edwards. 1994. The response of nematode trophic groups to organic and inorganic nutrient inputs in agroecosystems. Pp. 235-244. In: J.W. Doran, D.C. Coleman, D.F. Bezdicek, and B.A. Stewart (Eds). Defining soil quality for a sustainable environment. SSSA Special Publication No. 35. SSSA, ASA, Madison, WI.

Bollag, J.M., C.J. Meyers, and R.D. Minard. 1992. Biological and chemical interactions of pesticides with soil organic matter. Science of the Total Environment 123:205-217.

Boman, R.K., S.L. Taylor, W.R. Raun, G.V. Johnson, D.J. Bernardo, and L.L. Singleton. 1996. The Magruder Plots: A century of wheat research in Oklahoma. Published by Department of Agronomy, Oklahoma State University.

Bosch, D.J. and K.B. Napit. 1992. Economics of transporting poultry litter to achieve more effective use as fertilizer. J. of Soil and Water Cons. 47(4):342-346.

Brown, S.M.A., H.F. Cook, and H.C. Lee. 2000. Topsoil characteristics from a paired farm survey of organic versus conventional farming in southern England. Biological Agriculture \& Horticulture 18(1):37-54.

Buckman, H.O. and N.C. Brady. 1969. The nature and properties of soils ( $7^{\text {th }}$ Ed.). MacMillan Co., New York, NY.

Bullock, L.R. III, and J.B. Risaino. 1999. Effects of organic and synthetic fertility amendments on southern blight, soil biological communities and yield of processing tomatoes. In: G.B. 
Havenstein (Ed). Proceedings of 1999 NC State University Animal Waste Management Symposium; January 27-28, 1999; Research Triangle Park, NC. NCSU Animal Waste Management Field Day Committee; College of Agriculture and Life Sciences: NC State University, Raleigh, NC.

Burn, R.S. 1889. Farming and farming economy: Notes, historical and practical, on farming and farming economy. Crosby Lockwood and Son, London, UK.

Bushee, E.L., D.R. Edwards, R.S. Gates, L.W. Turner, P.A. Moore, and L. Dunn. 1999. Effects of chemical amendments on surface water runoff concentrations from swine manure. ASAE paper No. 99-2099.

Buyanovsky, G.A. and G.H. Wagner. 1998. Changing role of cultivated land in the global carbon cycle. Biology and Fertility of Soils 27:242-245.

Cabrera, M.L., S.C. Chiang, W.C. Merka, O.C. Pancorbo, and S.A. Thompson, 1994. Nitrous oxide and carbon dioxide emission from pelletized and nonpelletized poultry litter incorporated into soil. Plant and Soil 163:189-196.

Cabrera, M.L. and R.M. Gordillo. 1995. Nitrogen release from land-applied animal manures. In K. Steele (Ed.). Animal Waste and the Land-Water Interface, CRC Press, New York.

Campbell, A.J., J.A. Mcleod, and C. Stewart. 1997. Nutrient characterization of stored liquid hog manure. Can. Agric. Engin. 39:43-48.

CAST. 1992. Preparing U.S. agriculture for global climate change. Task Force Report No. 119, Council for Agricultural Science and Technology, Ames, IA, 96 pp.

CAST. 1995. Waste management and utilization in food production and processing. Council for Agricultural Science and Technology Report No. 124. Ames, IA. 125 p.

CAST. 1996. Integrated animal waste management. Council for Ag. Sci. and Tech., Ames, IA

Castellanos, J.Z. and P.F. Pratt. 1981. Mineralization of manure nitrogen: Correlation with laboratory indexes. Soil Sci. Soc. of Am. J. 45:354-357.

Chandra, S. and S.K. De. 1983. Effect of cattle manure on soil erosion by water. Soil Sci. 133:228-231.

Chang, C., T.G. Sommerfeldt, and T. Entz. 1990. Rates of soil chemical changes with eleven annual applications of cattle feedlot manure. Can. J. Soil Sci. 70:673-681.

Chang, C., T.G. Sommerfeldt, T. Entz. 1991. Soil chemistry after eleven annual applications of cattle feedlot manure. J. Env. Qual. 20:475-480.

Christensen, B.T. 1988. Effects of animal manure and mineral fertilizer on the total carbon and nitrogen contents of soil size fractions. Biology and Fertility of Soils 5:304-307.

Coleman, D.C., R.V. Anderson, C.V. Cole, J.F. McClellan, L.W. Woods, J.A. Trofymow, and E.T. Elliot. 1984. Roles of protozoa and nematodes in nutrient cycling. Pp. 17-28. In R.L.Todd, and J.E. Giddons (Eds). Microbial-plant interactions. ASA Special Publication 47. ASA, CSSA and SSSA, Madison, WI.

Collins, H.P., P.E. Rasmussen, and C.L. Douglas, Jr. 1992. Crop rotation and residue management effects on soil carbon and microbial dynamics. Soil Sci. Soc. Amer. J. 56:783-788.

Conway, G.R. and J. N. Pretty. 1991. Unwelcome harvest agriculture and pollution. Earthscan Publications Ltd. London, England. 645 p.

Cook, M.N., S. Mostaghimi, and P.W. McClellen. 1998. Animal waste BMPs and the bacteriological quality of surface water. ASAE Paper 982030. St Joseph, MI.

Coyne, M.S., R.A. Gilfillen, R.W. Rhodes, and R.L. Blevins. 1995. Soil and fecal coliform trapping by grass filter strips during simulated rain. J. Soil and Water Cons. 50:405-408.

Crane, S.R. and J.A. Moore. 1986. Modeling enteric bacterial die-off: A review. Water, Air, and Soil Pollution 27:411-439.

Crane, S.R., P.W. Westerman, and M.R. Overcash. 1980. Die-off of fecal indicator organisms following land application of poultry manure. J. Environ. Qual. 9:531-537.

Doran, J.W. and D.M. Linn. 1979. Bacteriological quality of runoff water from pastureland. App. and Envir. Microbiology. 37:985-991.

Dou, Z., J.D. Toth, D.T. Galligan, C.F. Ramberg, Jr., and J.D. Ferguson. 2000. Laboratory procedures for characterizing manure phosphorus. J. Environ. Qual. 29:508-514.

Dubrey, S.K. and Mondal, R.C. 1994. Effect of amendments and saline irrigation water on soil properties and yields of rice and wheat in a highly sodic soil. J. Agr. Sci. 122:351-357. 
During, C. and W.C. Weeda. 1973. Some effects of cattle dung on soil properties, pasture production, and nutrient uptake. I. Dung as a source of phosphorus. New Zealand J. Agric Res. $16: 423-430$.

Eck, H.V., S.R. Winter, and S.J. Smith. 1990. Sugarbeet yield and quality in relation to residual beef feedlot waste. Agron. J. 82:250-254.

Edwards, D.R., M.S. Coyne, T.C. Daniel, P.F. Vendrell, J.F. Murdoch, and P.A. Moore, Jr. 1997. Indicator bacteria concentration of two northwest Arkansas streams in relation to flow and season. Trans. ASAE 40:103-109.

Edwards, D.R. and T.C. Daniel. 1994. Environmental impacts of on-farm poultry waste disposal - a review. Bioresource. Technol. 41:9-33.

Edwards, D. R., T.C. Daniel, P.A. Moore, Jr., and A.N. Sharpley, 1994. Solids transport and erodibility of poultry litter surface applied to fescue. Trans. ASAE 37(3):771-776.

Edwards, J.H., R.H. Walker, E.A. Guertal, L.D. Norton, and J.T. Eason. 1994. Options for Recycling Organics on Farm Land. Biocycle 35(11):66-68.

Eghball, B. 1999. Liming effects of beef cattle feedlot manure or compost. Commun. Soil Sci. Plant Anal. 30:2563-2570.

Eghball, B. and J.F. Power. 1994. Beef cattle feedlot manure management. J. Soil and Water Cons. 49(2):113-122.

Eghball, B. and J.F. Power. 1999. Phosphorus and nitrogen-based manure and compost applications: Corn production and soil phosphorus. Soil Sci. Soc. Am. J. 63(4):895-901.

Ertl, D.S., K.A. Young, and V. Raboy. 1998. Plant genetic approaches to phosphorous management in agricultural production. J. Environ. Qual. 27:299-304.

Estevez, B., A. N'Dayegamiye, and D.Coderre. 1996. The effect of earthworm abundance and selected soil properties after 14 years of solid cattle manure and NPKMg fertilizer application. Can. J. of Soil Sci. 76(3):351-355.

Finlay-Moore, O., P.G. Hartel, and M.L. Cabrera. 2000. 17ß-estradiol and testosterone in soil and runoff from grasslands amended with broiler litter. J. Environ. Qual. 29:1604-1611.

Follett, R.H., D.G. Westfall, and R.L. Croissant. 1992. Utilization of animal manure as fertilizer. Colorado State University Cooperative Extension Bulletin 552A.

Franzluebbers, A.J., J.A. Stuedemann, and S.R. Wilkinson. 2001. Bermudagrass management in the Southern Piedmont USA. I. Soil and surface residue carbon and sulfur. Soil Sci. Soc. Am. J. 65:834-841.

Fraser, D.G., J.W. Doran, W.W. Sahs, and G.W. Lesoing. 1988. Soil microbial populations and activities under conventional and organic management. J. Environ. Qual. 17(4):585-590.

Freeze, B.S., and T.G. Sommerfeldt. 1985. Break-even hauling distances for beef feedlot manure in Southern Alberta. Can. J. Soil Sci. 65:687-693.

Frick, E.A. D.J. Hippe, G.R. Buell, C.A. Couch, E.H. Hopkins, D.J. Wangsness, and J. W. Garrett. 1998. Water quality in the Apalachicola, Chattahoochee-Flint river basin. U.S. Geological Survey. Report No. 1164. Reston, VA.

Gale, P.M., J.M. Phillips, M.L. May, and D.C. Wolf. 1991. Effect of drying on the plant nutrient content of hen manure. J. Prod. Agric. 4:246-250.

Gan, J., S.R. Yates, S. Papiernik, and D. Crowley. 1998. Application of organic amendments to reduce volatile pesticide emissions from soil. Env. Sci. \& Tech. 32(20):3094-3098.

Gary, H.L., S.R. Johnson, and S.L. Ponce. 1983. Cattle grazing impact on surface water quality in a Colorado front range stream. J. Soil and Water Cons. 38:124-128.

Geleta, S., G.J. Sabbagh, J.F. Stone, R.L. Elliot, H.P. Mapp, D.J. Bernardo, and K.B. Watkins. 1994. Importance of soil and cropping systems in the development of regional water quality policies. $J$. Env. Qual. 23(1):36-42.

Gerritse, R.G. and R. Vriesema. 1984. Phosphate distribution in animal waste slurries. J. Agric. Sci. (Cambridge) 102:159-161.

Giddens, J. and A.P. Barnett. 1980. Soil loss and microbiological quality of runoff from land treated with poultry litter. J. Environ. Qual. 9(3):518-520.

Gilbertson, C.B., F.A. Norstadt, A.C. Mathers, R.F. Holt, A.P. Barnett, T.M. McCalla, C.A. Onstad, and R.A. Young. 1979. Animal waste utilization on cropland and pastureland. USDA Utilization Res. Rep. 6. U.S. Government Printing Office. Washington, D.C. 
Gilbertson, C.B., L.R. Shuyler, J.A. Moore, and J.R. Miner. 1984. Livestock residue management and pollution control. In: Agriculture and the Environment: An Examination of Critical Issues for Food Policy, J.M. Sweeten and F.J. Humenik (Eds.). American Society of Agricultural Engineers, St. Joseph, Michigan. 117 p.

Gilley, J.E. and B. Eghball. 1998. Runoff and erosion following field application of beef cattle manure and compost. Trans. ASAE 41(5): 1289-1294.

Gilley, J.E., B. Eghball, J.M. Blumenthal, and D.D. Baltensperger. 1999. Runoff and erosion from interrill areas as affected by the application of manure. Trans. ASAE 42(4):975-980.

Gilley, J.E. and L. M. Risse. 2000. Runoff and soil loss as affected by the application of manure. Trans. ASAE 43(6):1583-1588.

Gollehon, N., M. Caswell, M. Ribaudo, R. Kellogg, C. Lander, and D. Letson, 2001. Confined Animal Production and Manure Nutrients. Resource Economics Division, Economic Research Service, U.S. Department of Agriculture. Agriculture Information Bulletin No. 771.

Gordillo, R.M. and M.L. Cabrera. 1997. Mineralizable nitrogen in broiler litter: I. Effect of selected litter chemical characteristics. J. Environ. Qual. 26:1672-1679.

Goss, D.W. and B.A. Stewart. 1979. Efficiency of phosphorus utilization by alfalfa from manure and superphosphate. Soil Sci Soc Am J 43:523-528.

Govi, M., O. Francioso, C. Ciavatta, P. Sequi. 1992. Influence of long-term residue and fertilizer applications on soil humic substances: A case study by electrofocusing. Soil Science 154:8-13.

Griffiths, B.S., K. Ritz, and R.E. Wheatley. 1994. Nematodes as indicators of enhanced microbiological activity in a Scottish organic farming system. Soil Use and Man.10(1):20-24.

Guibert, H., P. Fallavier, and J.J. Romero. 1999. Carbon content in soil particle size and consequence on cation exchange capacity of alfisols. Com. Soil Sci. Plant Anal. 30(17-18):25212537.

Guo, L., T.J. Bicki, T.D. Hinesley, and A.S. Felsot. 1991. Effect of carbon-rich waste materials on movement and sorption of atrazine in a sandy, coarse-textured soil. Environmental Toxicology and Chemistry 10:1273-1282.

Gupta, A.P., R.P. Narwal, R,S, Antil, and S. Dev. 1992. Sustaining soil fertility with organic-C, N, $\mathrm{P}$, and $\mathrm{K}$ by using farmyard manure and fertilizer-N in a semiarid zone: A long-term study. Arid Soil Research and Rehabilitation 6:243-251.

Gupta, G. and J. Baummer. 1996. Biodegradation of atrazine in soil using poultry litter. Journal of Hazardous Materials 45(2-3):185-192.

Harper, L.A., O.T. Denmead, J.R. Freney, and F.M. Byers. 1999. Direct measurements of methane emissions from grazing and feedlot cattle. Journal of Animal Science 77:1392-1401.

Harper, L.A., R.R. Sharpe, and T.B. Parkin. 2000. Gaseous nitrogen emissions from anaerobic swine lagoons: Ammonia, nitrous oxide, and dinitrogen gas. J. Environ. Qual. 29:1356-1365.

Hartel, P.G., W.I. Segars, J.D. Summer, J.V. Collins, A.T. Phillips, and E. Whittle. 2000. Survival of fecal coliforms in fresh and stacked broiler litter. J. Appl. Poultry Res. 9:505-512.

Haynes, R.J. and M.S. Mokolobate. 2001. Amelioration of Al toxicity and P deficiency in acid soils by addition of organic residues: A critical review of the phenomenon and the mechanisms involved. Nutrient Cycling in Agroecosystems 59(1):47-63.

Haynes, R.J. and R. Naidu. 1998. Influence of lime, fertilizer and manure applications on soil organic matter content and soil physical conditions: A review. Nutrient Cycling in Agroecosystems 51:123-137.

Holloway, M.P., A.B. Bottcher, and R. St. John. 1994. Design of a rotationally grazed dairy in North Florida. In: Environmentally Sound Agriculture, Proceedings of the Second Conference, K.L. Campbell, W.D. Grahman, and A.B. Bottcher (Ed). Orlando, Florida. Pp. 300-306.

Hue, N.V. 1992. Correcting soil acidity of a highly weathered ultisol with chicken manure and sewage sludge. Commun. Soil Sci. Plant Anal. 23:241-264.

Huffman, R.L. and P. W. Westerman. 1995. Estimated seepage losses from established swine lagoons in the lower coastal plain of North Carolina. Trans ASAE 38:449-453.

Hutson, J.L., R.E. Pitt, R. K. Koelsch, J.B. Houser, and R.J. Wagenet. 1998. Improving dairy farm sustainability II: Environmental losses and nutrient flows. J. Prod. Agric. 11(2):233-239.

Inbar, Y., Y. Chen, and Y. Hadar. 1990. Humic substances formed during the composting of organic matter. Soil Science Society of America Journal 54:1316-1323. 
Ingham, R.E., E.R. Trofymow, E.R. Ingham, and D.C. Coleman. 1985. Interactions of bacteria, fungi and their nematode grazers: Effects on nutrient cycling and plant growth. Ecological Monographs 5:119-140.

IPCC. 2000. Land use, land-use change and forestry. Intergovernmental Panel on Climate Change Special Report. Watson, R.T., Noble, I.R., Bolin, B., Ravindranath, N.H., Verardo, D.J., Dokken, D.J. (Eds). Cambridge University Press, UK, pp. 375.

Jackson, L.L., D.R. Keeney, and E.M. Gilbert. 2000. Swine manure management plans in North Central Iowa: Nutrient loading and policy implications. J. Soil and Water Cons. 55(2):205-212.

Jackson, W.A., S.R. Wilkinson, and R.A. Leonard. 1977. Land disposal of broiler litter: Changes in concentration of chloride, nitrate nitrogen, total nitrogen, and organic matter in a Cecil sandy loam. J. Environ. Qual. 6:58-62.

Jawson, M.D., L.F. Elliott, K.E. Saxton, and D.H. Fortier. 1982. The effect of cattle grazing on indicator bacteria in runoff from a Pacific Northwest watershed. J. Environ. Qual. 11:621-627.

Jokela, W.E. 1992. Nitrogen fertilizer and dairy manure effects on corn yield and soil nitrate. Soil Sci. Soc. Am. J. 56:148-154.

Kandeler, E., M. Stemmer, and E.M. Klimanek. 1999. Response of soil microbial biomass, urease and xylanase within particle size fractions to long-term soil management. Soil Biology and Biochemistry 31(2):261-273.

Kapkiyai, J.J., N.K. Karanja, J.N. Qureshi, P.C. Smithson, and P.L. Woomer. 1999. Soil organic matter and nutrient dynamics in a Kenyan nitisol under long-term fertilizer and organic input management. Soil Biology and Biochemistry 31(13):1773-1782.

Khaleel, R., G.R. Foster, K.R. Reddy, M.R. Overcash, and P.W. Westerman. 1979. A nonpoint source model for sediment and manure transport: III. A conceptual model for sediment and manure transport. Trans. ASAE 22(6):1362-1368.

Khaleel, R., K.R. Reddy, and M.R. Overcash. 1991. Changes in soil physical properties due to organic waste applications: A review. J. Environ. Qual. 10:133-141.

Kingery, W.L., C.W. Wood, D.P. Delaney, J.C. Williams, and G.L. Mullins. 1994. Impact of longterm land application of broiler litter on environmentally related soil properties. J. Environ. Qual. 23:139-147.

Kingery, W.L., C.W. Wood, D.P. Delaney, J.C. Williams, G.L. Mullins, and E. Vansanten. 1993. Implications of long-term land application of poultry litter on tall fescue pastures. J. Prod. Agric. 6(3):390-395.

Kirchmann, H. and M.H. Gerzabek. 1999. Relationship between soil organic matter and micropores in a long-term experiment at Ultuna, Sweden. Journal of Plant Nutrition and Soil Science 162(5):493-498.

Kubat, J., J. Novakova, D. Cerhanova, and R. Apfelthaler. 1999. Organic nitrogen cycle, ammonification and nitrification activity in long-term field experiment. Rostlinna Vyroba 45(9):397-402.

Kubat, J., J. Novakova, O. Mikanova, and R. Apfelthaler. 1999. Organic carbon cycle, incidence of microorganisms and respiration activity in long-term field experiment. Rostlinna Vyroba 45(9):389-395.

Kuykendall, H.A., M.L. Cabrera, C.S. Hoveland, M.A. McCann, and L.T. West. 1999. Stocking method effects on nutrient runoff from pastures with broiler litter. J. Environ. Qual. 28:18861890.

Lalande, R., B. Gagnon, R.R. Simard, and D. Cote. 2000. Soil microbial biomass and enzyme activity following liquid hog manure application in a long-term field trial. Can. J. Soil Sci. 80(2):263-269.

Lazarovits, G. 2001. Management of soil-borne pathogens with organic soil amendments: A disease control strategy salvaged from the past. Can. J. Plant Path. 23:1-7.

Levins, R.A., M.A. Schmitt, and D. Wynn Richardson. 1996. Extension programming for teaching manure management to farmers. Review of Agricultural Economics 18:275-280.

Liang, B.C. and A.F. Mackenzie. 1992. Changes in soil organic carbon and nitrogen after six years of corn production. Soil Science 153:307-313.

Loehr, R. 1984. Pollution Control For Agricultural, 2nd ED. Academic Press, Inc. Orlando. P. 42. 
Long, F.L., Z. F. Lund, and R. E. Hermanson. 1975. Effect of soil incorporated dairy cattle manure on runoff water quality and soil properties. J. Environ. Qual. 4(2):163-166.

Lowrance, R.R., L.S. Alter, J.D. Newbold, et al. 1995. Water quality functions of riparian forest buffer systems in the Chesapeake Bay Watershed. U.S. EPA, Washington, DC.

Magdoff, F.R. 1978. Influence of manure application rates and continuous corn on soil-N. Agron J 70:629-632.

Maihairaja, S., N.S. Bolan, M.J. Hedley, and A.N. MacGregor. 1990. Evaluation of methods of measurement of nitrogen in poultry and animal manures. Fert. Res. 24:141-148.

Marshall, S.B., C.W. Wood, L.C. Braun, M.L. Cabrera, M.D. Mullen, and E.A. Guertal. 1998. Ammonia volatilization from tall fescue pastures fertilized with broiler litter. J. Environ. Qual. 27:1125-1129.

May, D.M. and W.E. Martin. 1966. Manures are good sources of phosphorus. Calif. Agric 20:11-12.

Maynard, A.A. 1994. Sustained vegetable production for three years using composted animal manures. Compost Science and Utilization 2(1):88-96.

Meisinger, J.J. 1984. Evaluating plant available nitrogen in soil-crop systems. In R.D. Hauck (Ed.). Nitrogen in Crop Production. American Society of Agronomy, Crop Science Society Association, and Soil Science Society Association, Madison, Wisconsin. Pp. 391-416.

Meyer, D. and D.D. Mullinax, 1999. Livestock nutrient management concerns: Regulatory and legislative overview. J. Anim. Sci. 77(Suppl. 2/J):51-62.

Mielke, L.N. and A.P. Mazurak. 1976. Infiltration of water on a cattle feedlot. Trans. ASAE 19(2):341-344.

Millmier, A., J. Lorimor, C. Hurburth, Jr., C. Fulhage, J. Hattey, and H. Zhang. 2000. Trans. ASAE 43:903-908.

Miner, J.R., F.J. Humenik, and M.R. Overcash. 2000. Managing livestock waste to preserve environmental quality. Iowa State University Press. Ames, IA.

Mitchell, J.K. and R.W. Gunther. 1976. The effects of manure applications on runoff, erosion and nitrate losses. Trans ASAE 19(6):1104-1106.

Mondini, C., R. Chiumenti, F. da Borso, L. Leita, and M. De Nobili. 1996. Changes during processing in the organic matter of composted and air-dried poultry manure. Bioresource Technology 55:243-249.

Moore, P.A., Jr. and D.M. Miller. 1994. Decreasing phosphorus solubility in poultry litter with aluminum, calcium, and iron amendments. J. Environ. Qual. 23:325-330.

Moore, P.A. Jr., T.C. Daniel, A.N. Sharpley, and C.W. Wood. 1995. Poultry manure management: Environmentally sound options. J. Soil Water Cons. 50(3):321-327.

Mosaddeghi, M.R., M.A. Hajabbasi, A. Hemmat, and M. Afyuni. 2000. Soil compactibilty as affected by soil moisture content and farmyard manure in central Iran. Soil \& Tillage Research 55(1-2):87-97.

Motavalli, P.P., K.A. Kelling, and J.C Converse. 1989. First-year nutrient availability from injected dairy manure. J Environ. Qual. 18:180-185.

Mueller, D.H., R.C. Wendt, and T.C. Daniel. 1984. Soil and water losses as affected by tillage and manure application. Soil Sci. Soc. Am. J. 48(4):896-900.

Murray, J.A. 1910. Soils and Manures. Constable \& Company, London, UK.

Neher, D.A. and R.K. Olsen. 1999. Nematode communities in soils of four farm cropping management systems. Pedobiologia 43:430-438.

Nichols, D.J., T.C. Daniel, P.A. Moore, Jr., D.R. Edwards, and D.H. Pote. 1997. Runoff of estrogen hormone 17 beta-estradiol from poultry litter applied to pasture. J. Environ. Qual. 26: 10021006.

Nowak, P., R. Shepard, and F. Madison. 1998. Farmers and manure management: A critical analysis. In: Animal Waste Utilization: Effective use of Manure as a Soil Resource. J.L. Hatfield and B.A. Stewart (Ed). Ann Arbor Press, Chelsea, Michigan. Pp 1-32.

Nyakatawa, E.Z., K.C. Reddy, and K.R. Sistani. 2001. Tillage, cover cropping, and poultry litter effects on selected soil chemical properties. Soil \& Tillage Research 58:69-79.

Odell, J.D., M.E. Essington, and D.D. Howard. 1995. Surface application of liquid swine manure chemical variability. Commun. Soil Sci. Plant Anal. 26:19-20. 
Omenik, J.M. 1977. Nonpoint source stream nutrient level relationships: A nationwide study. EPA600/3-77-105. $150 \mathrm{pp}$.

Osmond, D.L., J. Spooner, and D.L. Line. 1995. Systems of best management practices for controlling agricultural nonpoint source pollution. RCWP Technology Tranfers Fact Sheet No. 6. North Carolina Cooperative Extension Service, N.C. State University, Raleigh, NC.

Parsons, R., J. Pease, and D. Kenyon. 1998. Economic and environmental impacts of nutrient management on dairy and dairy/poultry farms. Virginia Cooperative Extension Bulletin 448-031. Department of Agricultural and Applied Economics, Virginia Tech University.

Patterson, P.H., E.S. Lorenz, W.D. Weaver, and J.H. Schwartz. 1998. Litter production and nutrients from commercial broiler chickens. J. Appl. Poultry Res 7:247-252.

Paul, J.W. and E.G. Beauchamp. 1989. Effect of carbon constituents in manure on denitrification in soil. Canadian Journal of Soil Science 69:49-61.

Pell, A.N. 1997. Manure and microbes: Public and animal health problem? J. Dairy Sci 80:26732681.

Peterson, E.W., R.K. Davis, and H.A. Orndorff. 2000. $17 \beta$-estradiol as an indicator of animal waste contamination in mantled karst aquifers. J. Environ. Qual. 29:826-834.

Piccolo, A., P. Conte, I. Scheunert, and M. Paci. 1998. Atrazine interactions with soil humic substances of different molecular structure. J. Environ. Qual. 27(6):1324-1333.

Pimpini, F., L. Giardini, M. Borin, and G. Giaquinto. 1992. Effects of poultry manure and mineral fertilizers on the quality of crops. J Agric Sci 118:215-221.

Porter, G.A., G.B. Opena, W.B. Bradbury, J.C. Mc Burnie, and J.A. Sisson. 1999. Soil management and supplemental irrigation effects on potato: I. soil properties, tuber yield and quality. Agronomy Journal 91(3):416-425.

Pote, D.H., T.C. Daniel, A.N. Sharpley, P.A. Moore, Jr., D.R. Edwards, and D.J. Nichols. 1996. Relating extractable soil phosphorus to phosphorus losses in runoff. Soil Sci. Soc. Am. J. 60: 855859.

Qafoku, O.S., M.L. Cabrera, W.R. Windham, and N.S. Hill. 2001. Rapid methods to determine mineralizable nitrogen in broiler litter. J. Environ. Qual. 30:217-221.

Reeves, J.B., and J.A.S. Van Kessel. 1999. Investigations into near infrared analysis as an alternative to traditional procedures in manure nitrogen and carbon mineralization studies. Journal of Near Infrared Spectroscopy 7:195-212.

Richards, J.E. and C.P. Webster. 1999. Denitrification in the subsoil of the Broadbalk continuous wheat experiment. Soil Biology and Biochemistry 31:747-755.

Rieck-Hinz, A.M., G.A. Miller, and J.W. Schafer. 1996. Nutrient content of dairy manure from three handling systems. J. Prod. Agric. 9:82-86.

Roberts, R.J. and C.J. Clanton. 2000. Surface seal hydraulic conductivity as affected by livestock manure application. Trans. ASAE 43(3): 603-613.

Rochette, P., E. van Bochove, D. Prévost, D.A. Angers, D. Côté, and N. Bertrand. 2000. Soil carbon and nitrogen dynamics following application of pig slurry for the $19^{\text {th }}$ consecutive year. II. Nitrous oxide fluxes and mineral nitrogen. Soil Sci. Soc. Amer. J. 64:1396-1403.

Rynk, R. 1994. Status of dairy manure composting in North America. Compost Science \& Utilization 2(1):20-26.

Safley, L.M., Jr., P.W. Westerman, J.C. Barker, L.D. King, and D.T. Bowman. 1986. Slurry dairy manure as a corn nutrient source. Agric Wastes 18:123-136.

Sauer, T.J., T.C. Daniel, P.A. Moore, Jr., K.P. Coffey, D.J. Nichols, and C.P. West. 1999. Poultry litter and grazing animal effects on runoff water quality. J. Environ. Qual. 28(3):860-865.

Sawyer, J.E. and R.G. Hoeft. 1992. Corn production associated with liquid beef manure application methods. J. Prod. Agric. 4:335-344.

Schønning, P., B.T. Christensen, and B. Carstensen. 1994. Physical and chemical properties of a sandy loam receiving animal manure, mineral fertilizer or no fertilizer for 90 years. European Journal of Soil Science 45:245-268.

Serna., M.D. and F. Pomares. 1991. Comparison of biological and chemical methods to predict nitrogen mineralization in animal wastes. Biol. Fertil. Soils 12:89-94.

Sharpe, R.R. and L.A. Harper. 1997. Ammonium and nitrous oxide emissions from sprinkler irrigation applications to swine effluent. J. Environ. Qual. 26:1703-1706. 
Sharpley, A. and M. Meyer. 1994. Minimizing agricultural nonpoint-source impacts: A symposium overview. J. Environ. Qual 23(1):1-3.

Sharpley, A. and B. Moyer. 2000. Phosphorus forms in manure and compost and their release during simulated rainfall. J. Environ. Qual. 29:1462-1469.

Sharpley, A. and R. Sheffield. 2000. Phosphorus management. Lesson 8. USDA/EPA national curriculum project. http://www.mwpshq.org/curriculum_project/currproj.htm.

Sharpley, A.N., S.J. Smith, and R. Bain. 1993. Effect of poultry litter application on the nitrogen and phosphorus content of Oklahoma soils. Soil Sci. Soc. Am. J. 57:1131-1137.

Shore, L.S., D.L. Correl, and P.K. Chakraborty. 1995. Relationship of fertilization with chicken manure and concentrations of estrogens in small streams. In K. Steele (Ed). Animal waste and the land-water interface. Lewis Publishers. Boca Raton, FL. Pp.155-162.

Sims, J.T. 1986. Nitrogen transformations in a broiler manure amended soil: Temperature and moisture effects. J. Environ. Qual. 15:59-63.

Sims, J.T., R.R. Simard, and B.C. Joern. 1998. Phosphorus loss in agricultural drainage: Historical perspective and current research. J. Environ. Qual. 27:277-293.

Sommer, S.G., V. Kjellerup, and O. Kristjansen. 1992. Determination of total ammonium nitrogen in pig and cattle slurry: Sample preparation and analysis. Acta Agric. Scand. Sect. B, Soil and Plant Sci. 42:146-151.

Sommer, S.G., J.E. Olesen, and B.T. Christensen. 1991. Effects of temperature, wind speed and air humidity on ammonia volatilization from surface applied cattle slurry. J. Agric. Sci. (Cambridge) 117:91-100.

Sommerfeldt, T.G. and C. Chang. 1985. Changes in soil properties under annual applications of feedlot manure and different tillage practices. Soil Sci. Soc. Am. J. 49(4):983-987.

Sommerfeldt, T.G., C. Chang, and T. Entz. 1988. Long-term annual manure applications increase soil organic matter and nitrogen, and decrease carbon to nitrogen ratio. Soil Sci. Soc. Am. J 52:1668-1672.

Sørensen, P. and E.S. Jensen. 1995. Mineralization of carbon and nitrogen from fresh and anaerobically stored sheep manure in soils of different texture. Biology and Fertility of Soils 19:29-35.

Stanford, G. 1982. Assessment of soil nitrogen availability. In F.J. Stevenson (Ed.). Nitrogen Agric Soils Agron 22:651-688.

Stephenson, G.R. and L.V. Street. 1978. Bacterial variations in streams from a southwest Idaho rangeland watershed. J. Environ. Qual. 7:150-157.

Stewart, B.A. 1991. Effect of animal manure on soil physical and chemical properties. In: J. Blake, J. Donald and W. Magette (Eds). National Livestock, Poultry and Aquaculture Waste Management. Proceedings of the National Workshop; July 29-31, 1991: Kansas City, MO. ASAE St. Joseph, MI.

Strauch, D. and G. Ballarini, 1994. Hygienic aspects of the production and agricultural use of animal wastes. J. Vet. Med. B. 41:176-228.

Sweeten, J.M. 1992. Livestock and poultry waste management: A national overview. National Livestock, Poultry and Aquaculture Waste Management: Proceedings of the National Workshop. ASAE, St. Joseph, Michigan. Pp. 4-14.

Sweeten, J.M. and A.C. Mathers. 1985. Improving soils with livestock manure. J. Soil and Water Cons. 40(2):206-210.

Tchobanoglous, G. and E. Schroeder. 1987. Water Quality. Addison-Wesley Publishing Co., Reading Massachusetts.

Thelin, R. and G.F. Gifford. 1983. Fecal coliform release patterns from fecal material of cattle. $J$. Environ. Qual. 12:57-63.

Thompson, R.B., D. Morse, K.A. Kelling, and L.E. Lanyon. 1997. Computer programs that calculate manure application rates. J. Prod. Agric. 10:58-69.

Thompson, R.B., J.C. Ryden, and D.R. Lockyer. 1987. Fate of nitrogen in cattle slurry following surface application or injection to grassland. J. Soil Sci. 38:689-700.

Tiarks, A.E., A.P. Mazurak, and L. Chesnin. 1974. Physical and chemical properties of soil associated with heavy applications of manure from cattle feedlots. Soil Sci. Soc. Am. Proc. 38(5):826-830. 
Tiedmann, A.R. D.A. Higgens, T.M. Quigley, H.R. Sanderson, and C.C. Bohn. 1988. Bacterial water quality responses to four grazing strategies - comparisons with Oregon standards. $J$. Environ. Qual. 17:492-498.

Tim, U.S. and R. Jolly. 1994. Evaluating agricultural nonpoint source pollution using integrated geographical information systems and hydrologic/water quality models. . J. Environ. Qual. 23(1):25-35.

Tisdale, S.L., W.L. Nelson, J.D. Beaton, and J.L. Havlin. 1993. Soil Fertility and Fertilizers. $5^{\text {th }}$ ed. Prentice Hall, NJ.

USDA, 1998. Guide to minimize microbial food safety hazards for fresh fruits and vegetables. Food Safety Initiative Staff, HFS-32, U.S. Food and Drug Administration Center for Food Safety and Applied Nutrition. Washington, DC 202204. http:/www.foodsafety.gov/ dms/prodguid.html.

USDA, 2000. Comprehensive nutrient management planning technical guidance. A publication of the United States Department of Agriculture Natural Resources Conservation Service, December $1,2000$.

USDA-EPA, 1999. Unified national strategy for animal feeding operations.

U.S. EPA, 1998. National Water Quality Inventory:1998 Report to Congress. United States Environmental Protection Agency. http://www.epa.gov/305b/98report/index.html.

U.S. EPA, 2001a. National Pollutant Discharge Elimination System Permit Regulation and Effluent Limitations Guidelines and Standards for Concentrated Animal Feeding Operations. United States Environmental Protection Agency. http://www.epa.gov/npdes/pubs/cafo.pdf.

U.S. EPA, 2001b. Permit nutrient management plans (PNPs) versus comprehensive nutrient management plans (CNMPs). United States Environmental Protection Agency Office of Wastewater Management. http://cfpub1.epa.gov/npdes/afo/nutrient.cfm.

VanDyke, L.S., J.W. Pease, D.J. Bosch and J.C. Baker. 1999. Nutrient management planning on four Virginia livestock farms: Impacts on net income and nutrient losses. J. Soil Water Cons 54(2):499-505.

Van Kessel, J.S. and J.B. Reeves III. 2000. On-farm quick tests for estimating nitrogen in dairy manure. J. Dairy Sci. 83:1837-1844.

Vervoort, R.W., D.E. Radcliffe, M.L. Cabrera, and M. Latimore, Jr. 1998. Field-scale nitrogen and phosphorus losses from hayfields receiving fresh and composted broiler litter. J. Environ. Qual. $2 \&: 1246-1254$

Vitosh, M.L., J.F. Davis, and B.D. Knezek. 1973. Long-term effects of manure, fertilizer, and plow depth on chemical properties of soils and nutrient movement in a monoculture corn system. $J$. Environ. Qual. 2(2):296-299.

Vitosh, M.L., M.L. Person, and E.D. Purkhiser. 1988. Livestock manure management for efficient crop production and water quality preservation. Michigan State University Extension Bulletin WQ 12.

Vories, E.D., T.A. Costello and R.E. Glover. 1999. Impact of poultry litter on runoff from cotton fields. ASAE Paper No. 99-2196.

Wahid, A., S. Akhtar, I. Ali, and E. Rasul. 1998. Amelioration of saline-sodic soils with organic matter and their use for wheat growth. Comm. Soil Sci. Plant Anal. 29(15-16):2307-2318.

Wani, S.P., W.B. McGill, K.L. Haugen-Kozyra, J.A. Robertson, J.J. Thurston. 1994. Improved soil quality and barley yields with favabeans, manure, forages and crop rotation on a Gray Luvisol. Can. J. Soil Sci. 74:75-84.

Webster, C.P. and K.W.T. Goulding. 1989. Influence of soil carbon content on denitrification from fallow land during autumn. Journal of the Science of Food and Agriculture 49:131-142.

Westerman, P.W., T.L. Donnelly, and M.R. Overcash. 1983. Erosion of soil and poultry manure: A laboratory study. Trans ASAE 26(4):1070-1078, 1084.

Wong, M.T.E., S. Nortcliff, and R.S. Swift. 1998. Method for determining the acid ameliorating capacity of plant residue, urban waste compost, farmyard manure and peat applied to tropical soils. Comm. Soil Sci. Plant Anal. 29 (19-20):2927-2937.

Wood, B.H., C.W. Wood, K.H. Yoo, K.S. Yoon, and D.P. Delany. 1999. Seasonal surface runoff losses of nutrients and metals from soils fertilized with broiler litter and commercial fertilizer. $J$. Environ. Qual. 28(4):1210-1218. 
Wood, C.W. and B.M. Hall. 1991. Impact of drying method on broiler litter analyses. Commun. Soil Sci. Plant Anal. 22:1677-1688.

Xie, R.J. and A.F. MacKenzie. 1986. Urea and manure effects on soil nitrogen and corn dry matter yields. Soil Sci. Soc. Am. J. 50:1504-1509.

Zhang, H., D. Smeal, and J. Tomko. 1998. Nitrogen fertilization value of feedlot manure for irrigated corn production. J. Plant Nutrition, 21:287-296. 